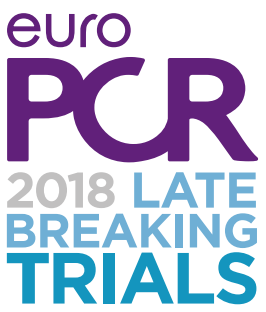

\title{
Complete two-year follow-up with formal non-inferiority testing on primary outcomes of the AIDA trial comparing the Absorb bioresorbable scaffold with the XIENCE drug-eluting metallic stent in routine $\mathrm{PCI}$
}

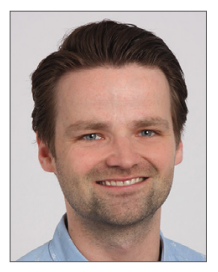

Ruben Y.G. Tijssen ${ }^{1}, \mathrm{MD}$; Robin P. Kraak ${ }^{1,2}, \mathrm{MD}$; Sjoerd H. Hofma ${ }^{3}, \mathrm{MD}$, PhD;

Rene J. van der Schaaf ${ }^{2}, \mathrm{MD}, \mathrm{PhD}$; E. Karin Arkenbout ${ }^{4}, \mathrm{MD}, \mathrm{PhD}$; Auke Weevers ${ }^{5}, \mathrm{MD}$; Joelle Elias ${ }^{1}, \mathrm{MD}$; Ivo M. van Dongen ${ }^{1}, \mathrm{MD}$; Karel T. Koch ${ }^{1}, \mathrm{MD}$, PhD; Jan Baan Jr${ }^{1}, \mathrm{MD}, \mathrm{PhD}$; M. Marije Vis ${ }^{1}, \mathrm{MD}, \mathrm{PhD}$; Robbert J. de Winter ${ }^{1}, \mathrm{MD}, \mathrm{PhD}$; Jan J. Piek ${ }^{1}, \mathrm{MD}, \mathrm{PhD}$; Jan G.P. Tijssen ${ }^{1}, \mathrm{PhD}$; Jose P.S. Henriques ${ }^{1}, \mathrm{MD}, \mathrm{PhD}$; Joanna J. Wykrzykowska ${ }^{*}$, MD, PhD

1. AMC Heartcenter, Academic Medical Center - University of Amsterdam, Amsterdam, the Netherlands; 2. Department of Cardiology, Onze Lieve Vrouwe Gasthuis, Amsterdam, the Netherlands, 3. Department of Cardiology, Medical Center Leeuwarden, Leeuwarden, the Netherlands; 4. Department of Cardiology, Tergooi Hospital, Blaricum, the Netherlands;

5. Department of Cardiology, Albert Schweitzer Hospital, Dordrecht, the Netherlands

R.Y.G. Tijssen and R.P. Kraak contributed equally to this manuscript.

This paper also includes supplementary data published online at: http://www.pcronline.com/eurointervention/137th_issue/76

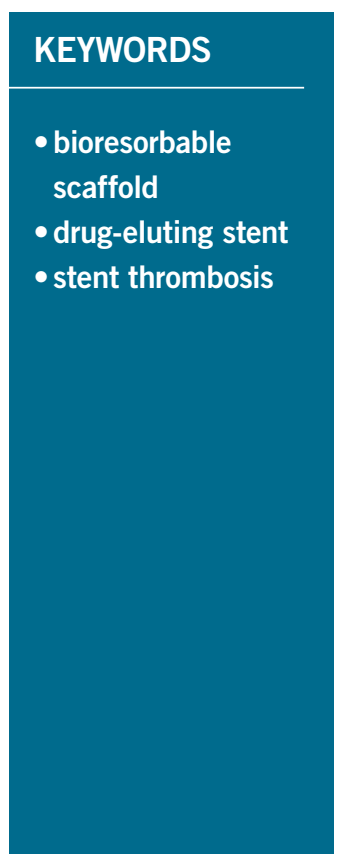

\section{Abstract}

Aims: The aim of this report of the AIDA trial is to provide full two-year outcomes for the primary endpoint of target vessel failure (TVF) and an update on device thrombosis.

Methods and results: AIDA was a single-blind, multicentre, investigator-initiated, non-inferiority, randomised (1:1) clinical trial. At complete two-year follow-up, the primary endpoint of TVF had occurred in 100 patients in the Absorb BVS arm versus 90 patients in the XIENCE EES arm (HR 1.12, 95\% CI: $0.94-1.49 ; \mathrm{p}_{\text {superiority }}=0.436$ ). Estimated two-year Kaplan-Meier event rates of TVF were $11.0 \%$ and $9.9 \%$, respectively ( $95 \%$ CI: $-0.9 \%-3.0 \%$; $\left.\mathrm{p}_{\text {non-inferiority }}=0.003\right)$. Definite or probable device thrombosis at two years occurred in 30 patients in the Absorb BVS arm and in eight patients in the XIENCE EES arm. KaplanMeier estimates of device thrombosis were $3.3 \%$ in the Absorb BVS arm and $0.9 \%$ in the XIENCE EES arm (HR 5.22, 95\% CI: 2.00-13.59; $<<0.001)$.

Conclusions: AIDA formally met its criterion for non-inferiority of Absorb BVS versus XIENCE EES in terms of the combined endpoint of TVF. The Absorb BVS, however, was associated with higher rates of scaffold thrombosis and target vessel myocardial infarction at complete two-year follow-up.

\footnotetext{
*Corresponding author: Department of Cardiology, Academic Medical Center - University of Amsterdam, Meibergdreef 9, 1105 AZ Amsterdam, the Netherlands.E-mail:j.j.wykrzykowska@amc.uva.nl
} 


\section{Abbreviations}

$\begin{array}{ll}\text { BVS } & \text { bioresorbable vascular scaffold } \\ \text { DAPT } & \text { dual antiplatelet therapy } \\ \text { DES } & \text { drug-eluting stent } \\ \text { DSMB } & \text { data and safety monitoring board } \\ \text { EES } & \text { everolimus-eluting stent } \\ \text { PCI } & \text { percutaneous coronary intervention } \\ \text { ScT } & \text { scaffold thrombosis } \\ \text { TLF } & \text { target lesion failure } \\ \text { TVF } & \text { target vessel failure } \\ \text { TVMI } & \text { target vessel myocardial infarction }\end{array}$

\section{Introduction}

Coronary bioresorbable vascular scaffolds were developed in order to overcome the shortcomings of conventional coronary metallic drug-eluting stents (DES) ${ }^{1}$. The most widely used and studied bioresorbable vascular scaffold was the Absorb everolimus-eluting bioresorbable vascular scaffold (Absorb BVS; Abbott Vascular, Santa Clara, CA, USA). The Absorb BVS received the Conformité Européenne (CE) mark in 2010 and was approved by the Food and Drug Administration (FDA) in 2016. While it gained acceptance in ordinary practice, no adequately powered, randomised, all-comers study addressing the safety and efficacy of the Absorb BVS had been performed at the time of commercialisation. Between 2013 and 2015 we performed the Amsterdam Investigator-initiateD Absorb strategy (AIDA) trial comparing the Absorb BVS with the XIENCE everolimus-eluting stent family (XIENCE EES; Abbott Vascular) in a population reflecting daily clinical practice with a primary endpoint of target vessel failure (TVF) at two years.

The data and safety monitoring board (DSMB) observed an increased rate of early and late scaffold thrombosis (ScT) and recommended considering prolonged dual antiplatelet therapy (DAPT) in all patients treated with Absorb BVS, as well as early reporting of the then available outcomes. This recommendation was implemented and the preliminary results with a median follow-up of 707 days were published ${ }^{2}$. In this manuscript, we report the full two-year primary outcomes and all clinical outcomes following treatment with Absorb BVS and XIENCE EES in the AIDA trial.

\section{Editorial, see page 373}

\section{Methods}

\section{STUDY DESIGN}

The AIDA trial was a single-blind, multicentre, investigator-initiated, non-inferiority, randomised (1:1) clinical trial. The study design and oversight of the AIDA trial have been described previously ${ }^{3}$.

AIDA enrolled patients with coronary artery disease who were eligible for inclusion if they were undergoing PCI, and were suitable candidates for treatment with a DES in accordance with the applicable guidelines and instructions for use (IFU) of the Absorb BVS and XIENCE EES families. Key exclusion criteria were target lesions longer than $70 \mathrm{~mm}$, a reference vessel diameter of
$<2.5 \mathrm{~mm}$ or $>4.0 \mathrm{~mm}$ estimated visually and treatment of bifurcation lesions in which a two-device strategy was planned, and treatment of in-stent restenosis. All included patients provided oral and written informed consent. In case of urgent PCI, oral consent was given before randomisation, and full written consent was obtained after the procedure.

After successful predilatation of the first lesion, patients were randomised to either Absorb BVS or XIENCE EES. Randomisation was performed with the use of a centralised web-based system in random block sizes. Patients were blinded to the study-group assignment, operators were not. During the first year of enrolment, scaffolds were implanted according to the manufacturer's IFU, which, at that time, did not include mandatory post-dilatation. Post-dilatation was performed in $63 \%$ of the lesions in the scaffold group during the first year of enrolment. After the IFU changed, the steering committee recommended routine post-dilatation of the Absorb BVS-treated lesions from October 2014 onwards. DAPT was administered according to the guidelines of the European Society of Cardiology and the IFU of the Absorb BVS or the XIENCE EES. DAPT was recommended for at least one year after scaffold implantation in patients with acute coronary syndrome. Due to unexpected higher rates of ScT, the DSMB recommended a cross-sectional data sweep in November 2016 and consequent publication of the descriptive information (without formal hypothesis testing) on all endpoint events that occurred before December $2016^{2}$. At the time of the publication of the preliminary results, all patients were unblinded and informed.

Clinical endpoints have been described previously and included the primary endpoint of target vessel failure (TVF), a composite of cardiac death, myocardial infarction and target vessel revascularisation, at two years (powered for non-inferiority) ${ }^{3}$. Secondary endpoints were all-cause death, all myocardial infarctions, all revascularisations, and device thrombosis. All myocardial infarctions were defined by the third universal definition of myocardial infarction and all other events were defined according to the Academic Research Consortium definitions ${ }^{4,5}$. An independent clinical events committee adjudicated all reported adverse events. Follow-up is ongoing annually up to five years, and is currently complete up to two years. Baseline SYNTAX score calculations were performed by the core laboratory staff of Cardialysis BV (Rotterdam, the Netherlands).

\section{STATISTICAL ANALYSIS}

This report provides the pre-specified two-year primary endpoint analysis from the AIDA trial. The AIDA trial was designed to test whether Absorb BVS was non-inferior to XIENCE EES, as determined by the rates of TVF at two years. To satisfy the non-inferiority hypothesis, the upper limit of the (two-sided) 95\% confidence interval for the rate difference (equivalent to non-inferiority testing at a one-sided alpha level of $2.5 \%$ ) had to fall below a pre-specified margin of 4.5 percentage points. Under the assumption of a $7.3 \%$ event rate for the primary endpoint at two years and a rate of loss to follow-up of $3.0 \%$, we estimated that we would need to enrol 
1,790 patients for the study to have at least $95 \%$ power. The first version of the protocol included a non-inferiority margin of 3.3 percentage points, which required enrolment of 2,690 patients for $90 \%$ power. After publication of the results of the ABSORB III trial, we amended the protocol, on the basis of FDA guidance, to adopt the non-inferiority margin of 4.5 percentage points used in that trial ${ }^{6}$. At the time that the protocol change was approved by the institutional review board in December 2015, a total of 1,845 patients had been enrolled, and enrolment was complete.

Analyses of primary and secondary endpoints were performed according to the intention-to-treat principle. Two-year event rates were based on Kaplan-Meier estimates in time-to-event analyses. Follow-up of the patients was censored at 730 days or at the last known event-free time point, whichever came first. For time-toevent analysis, hazard ratios with $95 \%$ confidence intervals were determined, and Kaplan-Meier curves were compared by means of the log-rank test.

For non-inferiority testing of the primary endpoint of TLF, we calculated the $95 \%$ confidence interval for the rate difference (the rate in the scaffold group minus the rate in the stent group) according to the method of Com-Nougue with the use of two-year KaplanMeier estimates of the TVF rate and Greenwood estimators of the standard error. We used the chi-square test or Fisher's exact test to compare categorical variables and the independent t-test to compare continuous variables. All statistical analyses were performed with SPSS software, Version 23.0 (IBM Corp., Armonk, NY, USA).

\section{Results}

Between August 2013 and December 2015, AIDA enrolled 1,845 patients, of whom 924 were randomised to treatment with Absorb BVS and 921 to XIENCE EES. The baseline characteristics in the two study arms were well balanced and have been reported previously $^{2}$ (Table 1). At complete two-year follow-up, clinical status was known in $96.9 \%$ of the patients (Supplementary Figure 1).

Procedural characteristics have been reported previously ${ }^{2}$ (Table 2). Briefly, a total of 2,446 lesions were treated. Successful implantation of at least one or more study devices was achieved in 895/924 (96.7\%) patients in the Absorb BVS arm and in 919/921 (99.8\%) patients in the XIENCE EES arm. Only assigned study devices were implanted in 859/924 (93.0\%) patients in the Absorb BVS arm versus 910/921 (98.8\%) in the XIENCE EES arm. The characteristics of the treated lesions are listed in Supplementary Table 1.

At complete two-year follow-up, TVF had occurred in 100 patients in the Absorb BVS arm versus 90 patients in the XIENCE EES arm

Table 1. Baseline characteristics of the patients*.

\begin{tabular}{|c|c|c|c|}
\hline \multicolumn{2}{|c|}{ Characteristics } & $\begin{array}{l}\text { Absorb BVS group } \\
\qquad \begin{array}{l}\mathrm{N}=924 \\
\end{array}\end{array}$ & $\begin{array}{l}\text { XIENCE EES group } \\
\qquad \mathrm{N}=921\end{array}$ \\
\hline \multicolumn{2}{|l|}{ Age, years } & $64.3 \pm 10.6$ & $64.0 \pm 10.5$ \\
\hline \multicolumn{2}{|l|}{ Male sex, n (\%) } & $670(73 \%)$ & $700(76 \%)$ \\
\hline \multirow[t]{7}{*}{ Risk factors, n/total n (\%) } & Diabetes mellitus & $171 / 924(19 \%)$ & $153 / 921(17 \%)$ \\
\hline & Requiring oral medication & $95 / 171(56 \%)$ & $97 / 153(63 \%)$ \\
\hline & Requiring insulin & $65 / 171(38 \%)$ & $45 / 153(37 \%)$ \\
\hline & Hypertension & $468 / 920(51 \%)$ & $464 / 919(51 \%)$ \\
\hline & Hypercholesterolaemia & $344 / 915(38 \%)$ & $350 / 914(38 \%)$ \\
\hline & Family history of coronary artery disease & $451 / 886(51 \%)$ & $469 / 886(53 \%)$ \\
\hline & Current smoker & $248 / 867(29 \%)$ & $273 / 861(32 \%)$ \\
\hline \multirow[t]{7}{*}{ History, n/total n (\%) } & Chronic renal failure & $70 / 924(8 \%)$ & $91 / 921(10 \%)$ \\
\hline & Ejection fraction $<30 \%$ & $22 / 910(2 \%)$ & $17 / 900(2 \%)$ \\
\hline & Previous stroke or transient ischaemic attack & $46 / 923(5 \%)$ & $58 / 921(6 \%)$ \\
\hline & Peripheral vascular disease & $65 / 924(7 \%)$ & $56 / 918(6 \%)$ \\
\hline & Previous myocardial infarction & $166 / 924(18 \%)$ & $172 / 921(19 \%)$ \\
\hline & Previous percutaneous coronary intervention & $202 / 924(22 \%)$ & $184 / 921(20 \%)$ \\
\hline & Previous bypass surgery & $38 / 924(4 \%)$ & $26 / 921(3 \%)$ \\
\hline \multirow[t]{6}{*}{ Clinical presentation, $\mathrm{n}(\%)$} & ST-segment elevation myocardial infarction & $240(26 \%)$ & 225 (24\%) \\
\hline & Non ST-segment elevation myocardial infarction & $185(20 \%)$ & $192(21 \%)$ \\
\hline & Unstable angina & $70(8 \%)$ & $87(9 \%)$ \\
\hline & Stable angina and/or documented ischaemia & $361(39 \%)$ & $370(40 \%)$ \\
\hline & Angiographically driven & $51(6 \%)$ & $36(4 \%)$ \\
\hline & Other & $17(2 \%)$ & $11(1 \%)$ \\
\hline \multirow[t]{2}{*}{ SYNTAX score } & Mean & $13.2 \pm 8.6$ & $12.6 \pm 8.4$ \\
\hline & Median (interquartile range) & $11(7-18)$ & $11(7-17)$ \\
\hline
\end{tabular}


Table 2. Procedural characteristics at baseline*.

\begin{tabular}{|c|c|c|c|c|}
\hline \multicolumn{2}{|r|}{ Outcome } & Absorb BVS group & XIENCE EES group & $p$-value \\
\hline \multicolumn{5}{|l|}{ Patients } \\
\hline \multicolumn{2}{|l|}{ Total number } & 924 & 921 & - \\
\hline \multicolumn{2}{|l|}{ Treated lesions per patient } & $1.34 \pm 0.63$ & $1.31 \pm 0.59$ & 0.360 \\
\hline \multicolumn{2}{|c|}{ Number of devices per patient } & $1.54 \pm 0.84$ & $1.45 \pm 0.79$ & 0.014 \\
\hline \multicolumn{2}{|c|}{ Total device length per patient, $\mathrm{mm}$} & $31.1 \pm 19.6$ & $29.7 \pm 19.2$ & 0.113 \\
\hline \multicolumn{2}{|c|}{ Minimum device diameter per patient, mm } & $2.73 \pm 0.27$ & $2.88 \pm 0.35$ & 0.050 \\
\hline \multirow[t]{6}{*}{ Device implantation, $\mathrm{n}(\%)$} & Any assigned study device & $895(96.9 \%)$ & $919(99.8 \%)$ & $<0.001$ \\
\hline & Only assigned study devices & 859 (93.0\%) & $910(98.8 \%)$ & $<0.001$ \\
\hline & Any unassigned device & $65(7.0 \%)$ & $11(1.2 \%)$ & $<0.001$ \\
\hline & Only unassigned devices & $29(3.1 \%)$ & $2(0.2 \%)$ & $<0.001$ \\
\hline & After failure assigned device & 20 & 1 & - \\
\hline & Unassigned device first choice & 9 & 1 & - \\
\hline \multicolumn{2}{|c|}{ Procedure time, min mean (total $n$ ) \pm SD } & $49(919) \pm 26$ & $44(918) \pm 23$ & $<0.001$ \\
\hline \multicolumn{2}{|c|}{ Contrast use, $\mathrm{ml}$ mean (total $\mathrm{n}$ ) $\pm \mathrm{SD}$} & $160(902) \pm 74$ & $151(897) \pm 72$ & 0.016 \\
\hline \multicolumn{2}{|c|}{ Predilatation first treated lesion, $\mathrm{n}(\%)$} & $911(99 \%)$ & $892(97 \%)$ & 0.012 \\
\hline \multicolumn{2}{|l|}{ Procedure success } & $834(90 \%)$ & $889(97 \%)$ & $<0.001$ \\
\hline \multicolumn{5}{|l|}{ Treated lesions $\pi$} \\
\hline \multicolumn{2}{|l|}{ Total number } & 1,237 & 1,209 & - \\
\hline \multicolumn{2}{|c|}{ Rotational atherectomy, n/total $\mathrm{n}$ of target lesions (\%) } & $24 / 1,232(1.9 \%)$ & $26 / 1,208(2.2 \%)$ & 0.776 \\
\hline \multicolumn{2}{|c|}{ Predilatation performed, $\mathrm{n}(\%)$} & $1,199(97 \%)$ & $1,103(91 \%)$ & $<0.001$ \\
\hline \multicolumn{2}{|c|}{ Total number of devices implanted } & 1,425 & 1,336 & - \\
\hline \multicolumn{2}{|l|}{ Number of devices per lesion } & $1.15 \pm 0.40$ & $1.11 \pm 0.34$ & 0.001 \\
\hline \multicolumn{2}{|c|}{ Post-dilatation performed, n (\%) } & $915(74 \%)$ & $594(49 \%)$ & $<0.001$ \\
\hline
\end{tabular}

(HR 1.12, 95\% CI: 0.94-1.49; $\mathrm{p}_{\text {superiority }}=0.436$ ). Estimated two-year Kaplan-Meier event rates of TVF were $11.0 \%$ and $9.9 \%$, respectively, 95\% CI: $-0.9 \%-3.0 \% ; p_{\text {non-inferiority }}=0.003$ ) (Figure 1, Table 3). Cardiac death occurred in 17 patients in the Absorb BVS arm and in 20 patients in the XIENCE EES arm, 1.9\% and 2.2\%, respectively (HR 0.85, 95\% CI: 0.44-1.62; $\mathrm{p}=0.618$ ). Rates of target vessel myocardial infarction (TVMI) were $5.1 \%$ in the Absorb BVS arm and $3.1 \%$ in the XIENCE EES arm (HR 1.65, 95\% CI: 1.03-2.64; $\mathrm{p}=0.034$ ). Rates of target vessel revascularisation (TVR) were $8.2 \%$ in the Absorb BVS arm and 7.0\% in the XIENCE EES arm (HR 1.18, 95\% CI: $0.84-1.65 ; \mathrm{p}=0.333$ ). Rates of TLR were $6.5 \%$ in the Absorb BVS arm and $4.8 \%$ in the XIENCE EES arm (HR 1.35, 95\% CI: $0.91-1.99$; $\mathrm{p}=0.133$ ). Rates of TLR caused by device thrombosis were $2.8 \%$ in the Absorb BVS arm and $0.5 \%$ in the XIENCE EES arm (HR 5.02, 95\% CI: 1.92-13.10; $\mathrm{p}<0.001$ ). Rates of TLR caused by device stenosis were $3.9 \%$ in the Absorb BVS arm versus $4.3 \%$ in the XIENCE EES arm (HR 0.89, 95\% CI: 0.57-1.41; $\mathrm{p}=0.626$ ).

Definite or probable device thrombosis at two years occurred in 30 patients in the Absorb BVS arm and in eight patients in the XIENCE EES arm. Kaplan-Meier estimates of device thrombosis were $3.3 \%$ in the Absorb BVS arm and $0.9 \%$ in the XIENCE EES arm (HR 5.22, 95\% CI: 2.00-13.59; $<<0.001$ ) (Table 4, Figure 2,

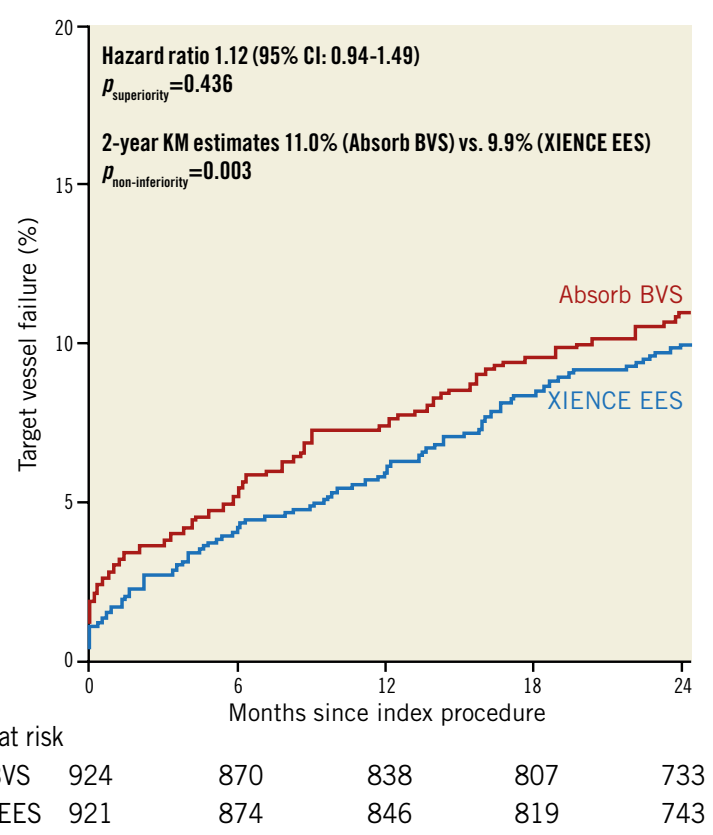

Figure 1. Kaplan-Meier curve for the composite endpoint of target vessel failure. Absorb BVS: Absorb bioresorbable vascular scaffold; KM: Kaplan-Meier; XIENCE EES: XIENCE everolimus-eluting stent 
Table 3. Safety and efficacy outcomes at 2-year follow-up*.

\begin{tabular}{|c|c|c|c|c|c|c|}
\hline & \multirow{2}{*}{$\begin{array}{l}\text { Absorb BVS } \\
\text { group } \\
(n=924)\end{array}$} & \multirow{2}{*}{$\begin{array}{l}\text { XIENCE EES } \\
\text { group } \\
(n=921)\end{array}$} & \multirow{2}{*}{$\begin{array}{l}\text { Hazard ratio for } \\
\text { Absorb BVS group } \\
\text { (95\% Cl) }\end{array}$} & \multirow[t]{2}{*}{$p$-value ${ }^{\pi}$} & \multicolumn{2}{|c|}{$\begin{array}{c}\text { Total number of events reported before } \\
\text { data lock on } 28 \text { February } 2018^{\ddagger}\end{array}$} \\
\hline & & & & & Absorb BVS group & XIENCE EES group \\
\hline \multicolumn{7}{|l|}{ Clinical events } \\
\hline All-cause death & $30(3.3)$ & $37(4.1)$ & $0.81(0.50-1.31)$ & 0.385 & 41 & 49 \\
\hline Cardiac & $17(1.9)$ & $20(2.2)$ & $0.85(0.44-1.62)$ & 0.618 & 22 & 24 \\
\hline Cardiovascular & $21(2.3)$ & $22(2.4)$ & $0.95(0.52-1.73)$ & 0.874 & 26 & 26 \\
\hline Non-cardiovascular & $9(1.0)$ & $15(1.5)$ & $0.60(0.26-1.37)$ & 0.218 & 15 & 23 \\
\hline All myocardial infarction & $59(6.5)$ & $37(4.1)$ & $1.61(1.07-2.42)$ & 0.022 & 69 & 46 \\
\hline Target vessel myocardial infarction & $46(5.1)$ & $28(3.1)$ & $1.65(1.03-2.64)$ & 0.034 & 53 & 33 \\
\hline During index procedure & $9(1.0)$ & $6(0.7)$ & $1.50(0.53-4.20)$ & 0.441 & 9 & 6 \\
\hline Not during index procedure & $37(4.1)$ & $22(2.4)$ & $1.69(1.00-2.86)$ & 0.049 & 44 & 26 \\
\hline Non-target vessel & $14(1.6)$ & $9(1.0)$ & $1.55(0.67-3.59)$ & 0.300 & 17 & 13 \\
\hline Death or myocardial infarction & $72(8.2)$ & $65(6.4)$ & $1.12(0.80-1.57)$ & 0.504 & 102 & 91 \\
\hline Any revascularisation & $115(12.8)$ & $98(10.8)$ & $1.18(0.90-1.54)$ & 0.237 & 133 & 117 \\
\hline Target vessel & $74(8.2)$ & $63(7.0)$ & $1.18(0.84-1.65)$ & 0.333 & 89 & 72 \\
\hline Target lesion & $59(6.5)$ & $44(4.8)$ & $1.35(0.91-1.99)$ & 0.133 & 69 & 51 \\
\hline Device thrombosis-related & $25(2.8)$ & $5(0.5)$ & $5.02(1.92-13.10)$ & $<0.001$ & 30 & 6 \\
\hline Device stenosis-related & 35 (3.9) & $39(4.3)$ & $0.89(0.57-1.41)$ & 0.626 & 40 & 45 \\
\hline Non-target lesion & $20(2.2)$ & $20(2.2)$ & $1.00(0.54-1.86)$ & 0.995 & 26 & 24 \\
\hline Non-target vessel & $58(6.5)$ & $48(5.3)$ & $1.20(0.82-1.76)$ & 0.345 & 65 & 61 \\
\hline \multicolumn{7}{|l|}{ Composite endpoints } \\
\hline Target vessel failure* & $100(11.0)$ & $90(9.9)$ & $1.12(0.94-1.49)$ & 0.436 & 120 & 103 \\
\hline Target lesion failure $\#$ & $88(9.7)$ & $75(8.0)$ & $1.18(0.87-1.61)$ & 0.290 & 103 & 86 \\
\hline Patient-oriented composite endpoint ${ }^{\Delta}$ & $155(17.0)$ & $140(15.3)$ & $1.09(0.88-1.34)$ & 0.352 & 184 & 170 \\
\hline \multicolumn{7}{|c|}{$\begin{array}{l}\text { *Percentages are Kaplan-Meier estimates of the rate of the endpoint at } 2 \text { years. "p-values were calculated by the log-rank test. \# Composite of cardiac } \\
\text { death, target vessel myocardial infarction and target lesion revascularisation. }{ }^{\Delta} \text { Composite of death from any cause, all myocardial infarction, or all } \\
\text { revascularisation. ₹No data sweep has been performed, therefore no } p \text {-value or KM estimates are given. Absorb BVS: Absorb bioresorbable vascular } \\
\text { scaffold; XIENCE EES: XIENCE everolimus-eluting stent }\end{array}$} \\
\hline
\end{tabular}

Table 4. Outcomes of device thrombosis at 2-year follow-up*.

\begin{tabular}{|c|c|c|c|c|c|c|}
\hline \multirow[t]{2}{*}{ Device thrombosis } & \multirow{2}{*}{$\begin{array}{c}\text { Absorb BVS } \\
\text { group } \\
(n=924)\end{array}$} & \multirow{2}{*}{$\begin{array}{c}\text { XIENCE EES } \\
\text { group } \\
(n=921)\end{array}$} & \multirow{2}{*}{$\begin{array}{l}\text { Hazard ratio for } \\
\text { Absorb BVS group } \\
\text { (95\% Cl) }\end{array}$} & \multirow[t]{2}{*}{$p$-value ${ }^{\pi}$} & \multicolumn{2}{|c|}{$\begin{array}{l}\text { Total number of events reported before } \\
\text { data lock on } 28 \text { February } 2018^{\ddagger}\end{array}$} \\
\hline & & & & & Absorb BVS group & XIENCE EES group \\
\hline Definite & $26(2.9)$ & $5(0.5)$ & $5.2(2.00-13.59)$ & $<0.001$ & 31 & 6 \\
\hline Probable & $4(0.4)$ & $3(0.3)$ & $1.33(0.30-5.93)$ & 0.710 & 4 & 3 \\
\hline Possible & $5(0.6)$ & $10(1.0)$ & $0.5(0.17-1.46)$ & 0.196 & 9 & 13 \\
\hline Definite/probable device thrombosis & $30(3.3)$ & $8(0.9)$ & $3.76(1.73-8.21)$ & $<0.001$ & 35 & 9 \\
\hline$\leq 24$ hours (acute) & 3 & 3 & - & - & 3 & 3 \\
\hline$>24$ hours to 30 days (subacute) & 10 & 2 & - & - & 10 & 2 \\
\hline 31 days to 1 year (late) & 8 & 1 & - & - & 8 & 1 \\
\hline $1-2$ years (very late) & 9 & 2 & - & - & 9 & 2 \\
\hline $2-3$ years (very late) & - & - & - & - & 4 & 0 \\
\hline 3-4 years (very late) & - & - & - & - & 1 & 0 \\
\hline $4-5$ years (very late) & - & - & - & - & 0 & 1 \\
\hline Any device thrombosis & 35 (3.9) & $18(2.0)$ & $1.96(1.11-3.46)$ & $<0.018$ & 44 & 22 \\
\hline
\end{tabular}


A

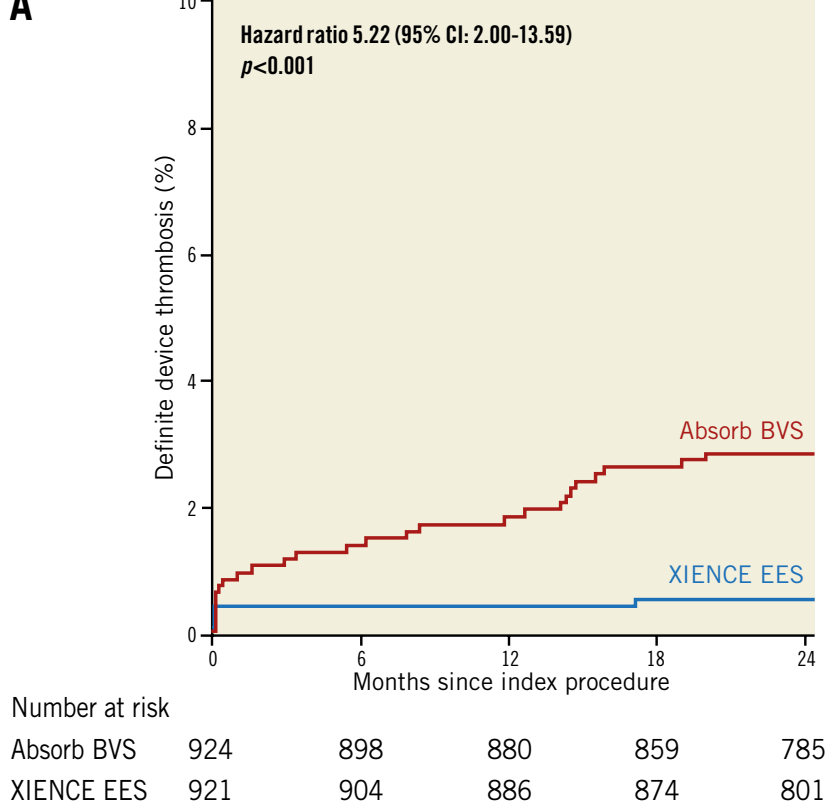

B

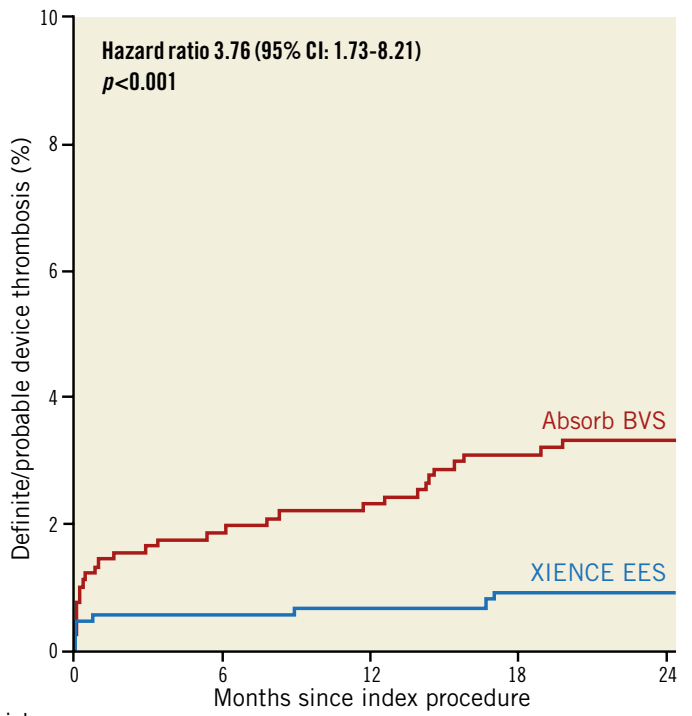

Number at risk

Absorb BVS 924

XIENCE EES 921

\begin{abstract}
898
880

886
\end{abstract}

859

873
785 800

Figure 2. Kaplan-Meier curve analysis. A) Definite device thrombosis. B) Definite or probable device thrombosis. Absorb BVS: Absorb bioresorbable vascular scaffold; XIENCE EES: XIENCE everolimus-eluting stent

Supplementary Table 2). At median follow-up of 1,092 days, definite or probable device thrombosis occurred in 35 patients in the Absorb BVS arm versus nine patients in the XIENCE EES arm. Very late device thrombosis occurred in 14 patients in the Absorb BVS arm versus three patients in the XIENCE EES arm. The 30-day landmark analysis for definite or definite and probable device thrombosis is shown in Supplementary Figure 2. The subgroup analysis of definite and probable ScT is shown in Supplementary Figure 3. Event rates at one year, and between one and two years, are shown in Supplementary Table $\mathbf{3}$ and Supplementary Table 4, respectively. Event rates of the "as treated population" and the "per protocol treatment population" are shown in Supplementary Table 5 and Supplementary Table 6, respectively.

\section{Discussion}

First, we found a slightly increased rate of TVF at two years (11.0\% versus 9.9\%) in Absorb BVS. Nevertheless, the 95\% CI for the rate difference in TVF fell below the pre-specified noninferiority criterion of $4.5 \%$. So, AIDA formally met its criterion for non-inferiority of Absorb BVS versus XIENCE EES in terms of TVF. Second, we found that Absorb BVS was associated with higher two-year rates of ScT and related myocardial infarction. Third, rates of TLR due to device thrombosis were statistically significantly higher in the Absorb BVS arm (2.8\% vs. $0.5 \%$; HR 5.02, 95\% CI: $1.92-13.10 ; \mathrm{p}<0.001)$. The rates of TLR not due to device thrombosis were similar.

The initial results of the first registries and clinical randomised trials with the Absorb BVS showed promising results with acceptable rates of TLF and ScT at one year. Initial enthusiasm was dampened when various studies reported increased rates of ScT as compared to conventional metallic DES ${ }^{7-9}$.

Efforts are ongoing to develop a second generation of safer bioresorbable coronary scaffolds. The hope is that, after absorption and integration processes are complete, event rates will be lower than those of DES. An analytic Markov model of the most recent updated corresponding meta-analyses of randomised clinical trials with Absorb BVS versus metallic stents, performed under the assumption of no scaffold thrombosis or TLR between three and 25 years, suggested that the observed three-year increased rate of ScT would be offset 19 years after $\mathrm{PCI}^{10}$. This means that the allowable excess risk of ScT during the first three years after scaffold implantation must decline significantly in order to justify the value of treatment with a bioresorbable scaffold.

Optimised scaffold implantation techniques have been suggested to mitigate the risk of early and late $\mathrm{ScT}^{11}$. However, serial OCT examples from the INVEST registry demonstrated that ScT also occurs in scaffolds with initially well apposed and well covered struts. This implies that additional non-procedural factors (such as intraluminal late scaffold disintegration) may contribute to the occurrence of $\mathrm{ScT}^{12,13}$. Due to the complex process of scaffold degradation and coronary vessel healing, the exact cause of the reported higher rates of (very) late ScT remain partly understood. Early ScT is most often caused by scaffold underexpansion, and late ScT is caused by scaffold malapposition, either pre-existent or acquired ${ }^{14}$.

After publication of the preliminary results of the AIDA trial, the steering committee and the Dutch Society of Cardiology advised considering restarting or prolonging DAPT for up to three years after scaffold implantation. In AIDA, twelve of thirteen cases of very late definite ScT occurred in patients who did 
not take DAPT at the time of the event (Supplementary Table 5). It is still not known whether DAPT is able to mitigate the risk of (very) late ScT. Full three-year follow-up of AIDA might shed light on this issue. Whether the risk of ScT disappears after three years remains to be seen. The four-year results of the ABSORB II trial were encouraging, with no additional scaffold thromboses reported beyond three-year follow-up ${ }^{15}$. However, in AIDA we observed one case of definite ScT at 1,277 days. We note that, currently, $63.6 \%$ of AIDA patients were randomised more than three years ago, but follow-up of these patients is limited. Long-term follow-up of AIDA will provide insights into the long-term risk of ScT beyond the expected time of scaffold resorption and integration (at three and five years, respectively). These insights could be useful for the development of future-generation bioresorbable coronary devices with broader expansion limits, better tensile strength and a more optimal resorption process.

\section{Limitations}

First, intracoronary imaging was not performed routinely. It is therefore not possible to distinguish between successful and unsuccessful lesion preparation and/or scaffold implantation. Second, post-procedural cardiac enzymes were only measured when clinically indicated. Therefore, potential post-procedural myocardial infarctions could have been missed. Third, restarting or prolonging DAPT therapy up to three years after scaffold implantation was recommended at the request of the DSMB. This recommendation might have influenced the occurrence of thrombosis-related outcomes in patients on prolonged or restarted DAPT compared to patients who were treated according to the applicable guidelines and IFU.

\section{Conclusions}

AIDA formally met its criterion for non-inferiority of Absorb BVS versus XIENCE EES in terms of the combined endpoint of TVF. The Absorb BVS, however, was associated with higher rates of scaffold thrombosis and target vessel myocardial infarction at complete two-year follow-up.

\section{Impact on daily practice}

Coronary bioresorbable vascular scaffolds were developed in order to overcome the shortcomings of conventional coronary metallic drug-eluting stents (DES). In AIDA, as in other trials, Absorb BVS was associated with higher rates of scaffold thrombosis and target vessel myocardial infarction than XIENCE EES. In spite of this, AIDA formally met its criterion for non-inferiority of Absorb BVS versus XIENCE EES in terms of TVF. Although Absorb is not available anymore, long-term follow-up of AIDA will provide insights into the long-term risk of scaffold thrombosis beyond the expected time of scaffold resorption and integration (at three and five years, respectively). These insights could be useful for the development of future-generation bioresorbable coronary devices with broader expansion limits and better tensile strength.

\section{Acknowledgement}

The AIDA study team is immensely grateful to Ineke Verhulst and all AMC interventional cardiology research fellows for their continuous support and assistance during the AIDA trial.

\section{Funding}

The AIDA trial was supported by an unrestricted educational grant from Abbott Vascular. The AMC Heart Center received an educational research grant from Abbott Vascular for the AIDA trial. The Research Department of the cardiology division of the Medical Center Leeuwarden received non-study-related unrestricted educational research grants from Abbott Vascular.

\section{Conflict of interest statement}

J. Piek is a member of the Medical Advisory Board of Abbott Vascular. J. Tijssen served on the DSMB of the early ABSORB trials, including ABSORB II. J. Henriques receives research grants from Abbott Vascular. J. Wykrzykowska receives consultancy fees and research grants from Abbott Vascular. The other authors have no conflicts of interest to declare.

\section{References}

1. Serruys PW, Garcia-Garcia HM, Onuma Y. From metallic cages to transient bioresorbable scaffolds: change in paradigm of coronary revascularization in the upcoming decade? Eur Heart J. 2012;33:16-25b.

2. Wykrzykowska JJ, Kraak RP, Hofma SH, van der Schaaf RJ, Arkenbout EK, IJsselmuiden AJ, Elias J, van Dongen IM, Tijssen RYG, Koch KT, Baan J Jr, Vis MM, de Winter RJ, Piek JJ, Tijssen JGP, Henriques JPS; AIDA Investigators. Bioresorbable Scaffolds versus Metallic Stents in Routine PCI. $N$ Engl J Med. 2017;376:2319-28.

3. Woudstra P, Grundeken MJ, Kraak RP, Hassell ME, Arkenbout EK, Baan J Jr, Vis MM, Koch KT, Tijssen JG, Piek JJ, de Winter RJ, Henriques JP, Wykrzykowska JJ. Amsterdam Investigator-initiateD Absorb strategy all-comers trial (AIDA trial): a clinical evaluation comparing the efficacy and performance of ABSORB everolimus-eluting bioresorbable vascular scaffold strategy vs the XIENCE family (XIENCE PRIME or XIENCE Xpedition) everolimus-eluting coronary stent strategy in the treatment of coronary lesions in consecutive all-comers: rationale and study design. Am Heart J. 2014;167:133-40.

4. Thygesen K, Alpert JS, Jaffe AS, Simoons ML, Chaitman BR, White HD; Joint ESC/ACCF/AHA/WHF Task Force for the Universal Definition of Myocardial Infarction, Katus HA, Lindahl B, Morrow DA, Clemmensen PM, Johanson P, Hod H, Underwood R, Bax JJ, Bonow RO, Pinto F, Gibbons RJ, Fox KA, Atar D, Newby LK, Galvani M, Hamm CW, Uretsky BF, Steg PG, Wijns W, Bassand JP, Menasché P, Ravkilde J, Ohman EM, Antman EM, Wallentin LC, Armstrong PW, Simoons ML, Januzzi JL, Nieminen MS, Gheorghiade M, Filippatos G, Luepker RV, Fortmann SP, Rosamond WD, Levy D, Wood D, Smith SC, Hu D, LopezSendon JL, Robertson RM, Weaver D, Tendera M, Bove AA, 
Parkhomenko AN, Vasilieva EJ, Mendis S. Third universal definition of myocardial infarction. Circulation. 2012;126:2020-35.

5. Cutlip DE, Windecker S, Mehran R, Boam A, Cohen DJ, van Es GA, Steg PG, Morel MA, Mauri L, Vranckx P, McFadden E, Lansky A, Hamon M, Krucoff MW, Serruys PW; Academic Research Consortium. Clinical end points in coronary stent trials: a case for standardized definitions. Circulation. 2007;115:2344-51.

6. Ellis SG, Kereiakes DJ, Metzger DC, Caputo RP, Rizik DG, Teirstein PS, Litt MR, Kini A, Kabour A, Marx SO, Popma JJ, McGreevy R, Zhang Z, Simonton C, Stone GW; ABSORB III Investigators. Everolimus-Eluting Bioresorbable Scaffolds for Coronary Artery Disease. N Engl J Med. 2015;373:1905-15.

7. Stone GW, Gao R, Kimura T, Kereiakes DJ, Ellis SG, Onuma Y, Cheong WF, Jones-McMeans J, Su X, Zhang Z, Serruys PW. 1-year outcomes with the Absorb bioresorbable scaffold in patients with coronary artery disease: a patient-level, pooled meta-analysis. Lancet. 2016;387:1277-89.

8. Serruys PW, Chevalier B, Dudek D, Cequier A, Carrié D, Iniguez A, Dominici M, van der Schaaf RJ, Haude M, Wasungu L, Veldhof S, Peng L, Staehr P, Grundeken MJ, Ishibashi Y, GarciaGarcia HM, Onuma Y. A bioresorbable everolimus-eluting scaffold versus a metallic everolimus-eluting stent for ischaemic heart disease caused by de-novo native coronary artery lesions (ABSORB II): an interim 1-year analysis of clinical and procedural secondary outcomes from a randomised controlled trial. Lancet. 2015;385:43-54.

9. Kimura T, Kozuma K, Tanabe K, Nakamura S, Yamane M, Muramatsu T, Saito S, Yajima J, Hagiwara N, Mitsudo K, Popma JJ, Serruys PW, Onuma Y, Ying S, Cao S, Staehr P, Cheong WF, Kusano H, Stone GW; ABSORB Japan Investigators. A randomized trial evaluating everolimus-eluting Absorb bioresorbable scaffolds vs. everolimus-eluting metallic stents in patients with coronary artery disease: ABSORB Japan. Eur Heart J. 2015;36:3332-42.

10. Capodanno D, Buccheri S, Romano S, Capranzano P, Francaviglia B, Tamburino C. Decision Analytic Markov Model Weighting Expected Benefits and Current Limitations of FirstGeneration Bioresorbable Vascular Scaffolds: Implications for Manufacturers and Next Device Iterations. Circ Cardiovasc Interv. 2018;11:e005768.

11. Stone GW, Abizaid A, Onuma Y, Seth A, Gao R, Ormiston J, Kimura T, Chevalier B, Ben-Yehuda O, Dressler O, McAndrew T, Ellis SG, Kereiakes DJ, Serruys PW. Effect of Technique on Outcomes Following Bioresorbable Vascular Scaffold Implantation: Analysis From the ABSORB Trials. J Am Coll Cardiol. 2017; 70:2863-74.

12. Yamaji K, Ueki Y, Souteyrand G, Daemen J, Wiebe J, Nef H, Adriaenssens T, Loh JP, Lattuca B, Wykrzykowska JJ, Gomez-Lara J, Timmers L, Motreff P, Hoppmann P, Abdel-Wahab M, Byrne RA,
Meincke F, Boeder $\mathrm{N}$, Honton B, O'Sullivan CJ, Ielasi A, Delarche N, Christ G, Lee JKT, Lee M, Amabile N, Karagiannis A, Windecker S, Räber L. Mechanisms of Very Late Bioresorbable Scaffold Thrombosis: The INVEST Registry. J Am Coll Cardiol. 2017;70:2330-44.

13. Yamaji K, Räber L, Windecker S. What determines long-term outcomes using fully bioresorbable scaffolds - the device, the operator or the lesion? EuroIntervention. 2017;12:1684-7.

14. Kraak RP, Kajita AH, Garcia-Garcia HM, Henriques JPS, Piek JJ, Arkenbout EK, van der Schaaf RJ, Tijssen JGP, de Winter RJ, Wykrzykowska JJ. Scaffold thrombosis following implantation of the ABSORB BVS in routine clinical practice: Insight into possible mechanisms from optical coherence tomography. Catheter Cardiovasc Interv. 2018 Jan 14. [Epub ahead of print].

15. Chevalier B, Cequier A, Dudek D, Haude M, Carrie D, Sabaté M, Windecker S, Reith S, de Sousa Almeida M, Campo G, Iniguez A, Onuma Y, Serruys PW. Four-year follow-up of the randomised comparison between an everolimus-eluting bioresorbable scaffold and an everolimus-eluting metallic stent for the treatment of coronary artery stenosis (ABSORB II Trial). EuroIntervention. 2018;13:1561-4.

\section{Supplementary data}

Supplementary Figure 1. Flow chart of patients included in the AIDA trial.

Supplementary Figure 2. 30-day landmark analysis with KaplanMeier curves for definite device thrombosis or definite and probable device thrombosis.

Supplementary Figure 3. Subgroup analysis of definite or probable scaffold thrombosis at complete two-year follow-up.

Supplementary Table 1. Characteristics of the treated lesions at baseline.

Supplementary Table 2. Descriptive characteristics of cases of definite device thrombosis.

Supplementary Table 3. Safety and efficacy outcomes at one-year follow-up.

Supplementary Table 4. Safety and efficacy outcomes between one- and two-year follow-up.

Supplementary Table 5. Safety and efficacy outcomes of the "as treated" population at two-year follow-up.

Supplementary Table 6. Safety and efficacy outcomes per protocol treatment at two-year follow-up.

The supplementary data are published online at:

http://www.pcronline.com/

eurointervention/137th issue/76 


\section{Supplementary data}

\section{Acknowledgements}

The AIDA study team would especially like to thank Ineke Verhulst for her continuous support during the collection of follow-up. Furthermore, we are immensely grateful to D. Ouweneel, M. Nassif, M. van Mourik, J. Velu, D. Kalkman, M. van Lavieren, P. van Brussel, G. Wijntjens, N. Hoedemaker, M. Beijk, K. Sjauw, E. Scheunhage, M. van 't Hul-Gorlewska, T. van de Hoef, L. Hoebers, H. Lu, E. Wiegerinck, M. Hassel, M. Grundeken and P. Woudstra for their assistance during the trial.

Supplementary Figure 1. Flow chart of patients included in the AIDA trial.

Absorb BVS: Absorb bioresorbable vascular scaffold; XIENCE EES: XIENCE everolimus-eluting stent

Supplementary Figure 2. 30-day landmark analysis with Kaplan-Meier curves for definite device thrombosis (A) or definite and probable device thrombosis (B).

Absorb BVS: Absorb bioresorbable vascular scaffold; CI: confidence interval; XIENCE EES: XIENCE everolimus-eluting stent

Supplementary Figure 3. Subgroup analysis of definite or probable device thrombosis at complete 2year follow-up. Percentages are Kaplan-Meier estimates of the endpoint at 2-year follow-up. P-value for interaction between the variable and relative treatment effects. Patients with multiple target lesions were classified according to the most complex lesion treated. All subgroup analyses are prespecified, except the 'Time of randomisation', and 'Patients per site'.

Absorb BVS: Absorb bioresorbable vascular scaffold; ACS: acute coronary syndrome; AHA/ACC: American Heart Association/American College of Cardiology; CI: confidence interval; XIENCE EES: XIENCE everolimus-eluting stent

Supplementary Table 1. Characteristics of the treated lesions at baseline. $¥$ Target lesion measures as reported by the site. ๆ Visual estimation. Plus-minus values are means $\pm S D$. Absorb BVS: Absorb bioresorbable vascular scaffold; AHA/ACC: American Heart Association/American College of Cardiology; XIENCE EES: XIENCE everolimus-eluting stent

Supplementary Table 2. Descriptive characteristics of cases of definite device thrombosis.

Absorb BVS: Absorb bioresorbable vascular scaffold; XIENCE EES: XIENCE everolimus-eluting stent; AO-OM: aorta-obtuse marginal; AP: angina pectoris; ASA: aspirin; DAPT: dual antiplatelet therapy; 
HIV: human immunodeficiency virus ; LAD: left anterior descending coronary artery; NSTEMI: non-STelevation myocardial infarction; MI: myocardial infarction; OAC: oral anticoagulant medication; OCT: optical coherence tomography; OM: obtuse marginal; RCA: right coronary artery; RcX: ramus circumflex; ST: scaffold thrombosis; STEMI: ST-elevation myocardial infarction; UAP: unstable angina pectoris; UN: unknown 
Supplementary Table 3. Safety and efficacy outcomes at 1-year follow-up.

$\$$ Percentages are Kaplan-Meier estimates of the rate of the endpoint at 1 year. " P-values were calculated by the log-rank test. " Composite of cardiac death, target vessel myocardial infarction and target lesion revascularisation. ${ }^{*}$ Composite of death from any cause, all myocardial infarction, or all revascularisation. Absorb BVS: Absorb bioresorbable vascular scaffold; XIENCE EES: XIENCE everolimus-eluting stent

Supplementary Table 4. Safety and efficacy outcomes between 1st and 2nd year follow-up.

${ }^{\$}$ Percentages are Kaplan-Meier estimates of the rate of the endpoint at 2 years. " P-values were calculated by the log-rank test. " Composite of cardiac death, target vessel myocardial infarction and target lesion revascularisation. ${ }^{*}$ Composite of death from any cause, all myocardial infarction, or all revascularisation. Absorb BVS: Absorb bioresorbable vascular scaffold; XIENCE EES: XIENCE everolimus-eluting stent

Supplementary Table 5. Safety and efficacy outcomes in the "as treated" population at 2-year follow-up.

\$Percentages are Kaplan-Meier estimates of the rate of the endpoint at 2 years. " P-values were calculated by the log-rank test. \# Composite of cardiac death, target vessel myocardial infarction and target lesion revascularisation. ${ }^{*}$ Composite of death from any cause, all myocardial infarction, or all revascularisation. Absorb BVS: Absorb bioresorbable vascular scaffold; XIENCE EES: XIENCE everolimus-eluting stent

Supplementary Table 6. Safety and efficacy outcomes per protocol treatment at 2-year follow-up.

\$ Percentages are Kaplan-Meier estimates of the rate of the endpoint at 2 years. " P-values were calculated by the log-rank test. " Composite of cardiac death, target vessel myocardial infarction and target lesion revascularisation. ${ }^{*}$ Composite of death from any cause, all myocardial infarction, or all revascularisation. Absorb BVS: Absorb bioresorbable vascular scaffold; XIENCE EES: XIENCE everolimus-eluting stent 
Supplementary Figure 1. Flow chart of patients included in the AIDA trial.

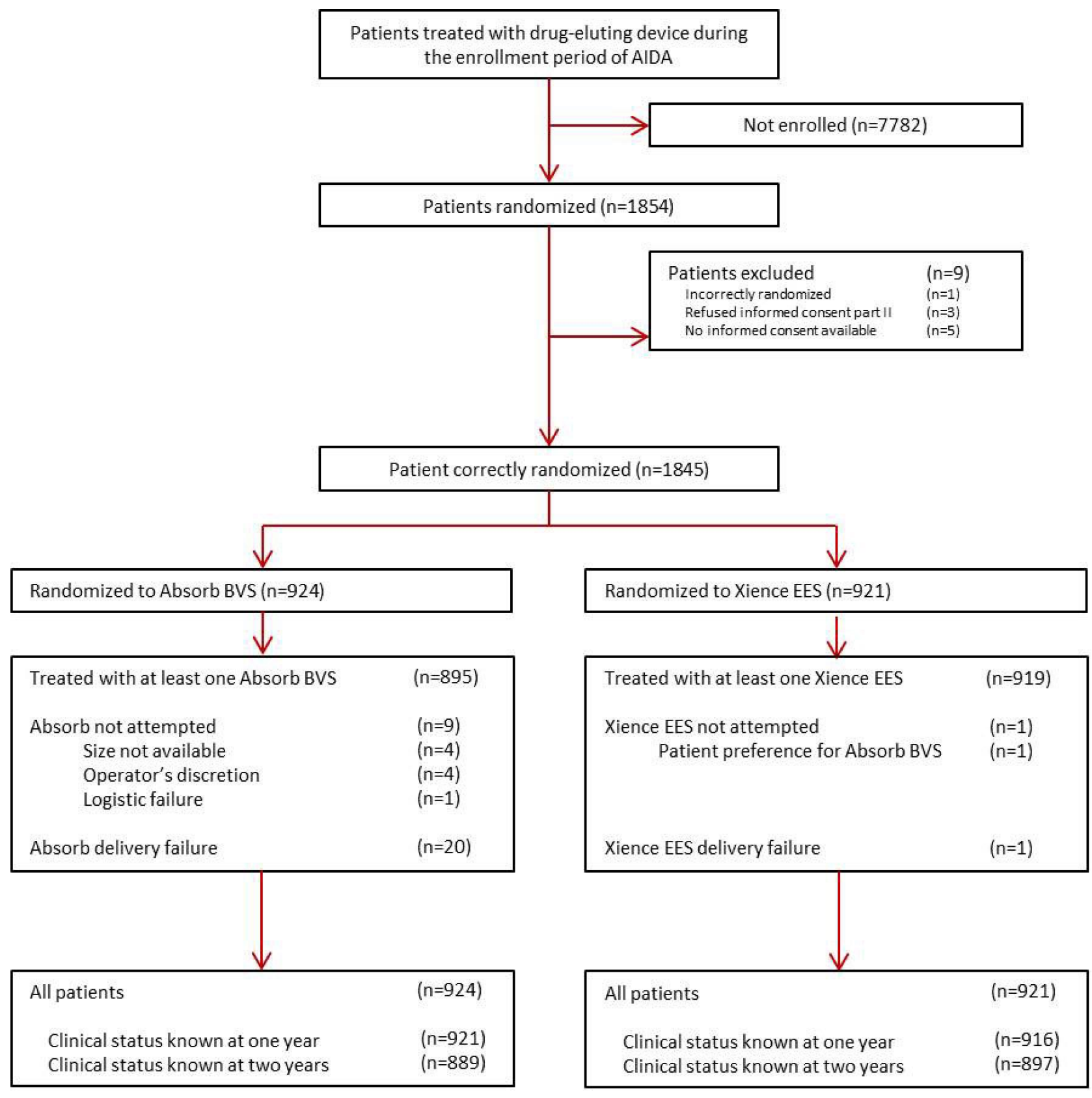


Supplementary Figure 2. 30-day landmark analysis with Kaplan-Meier curves for definite device thrombosis (A) or definite and probable device thrombosis (B).

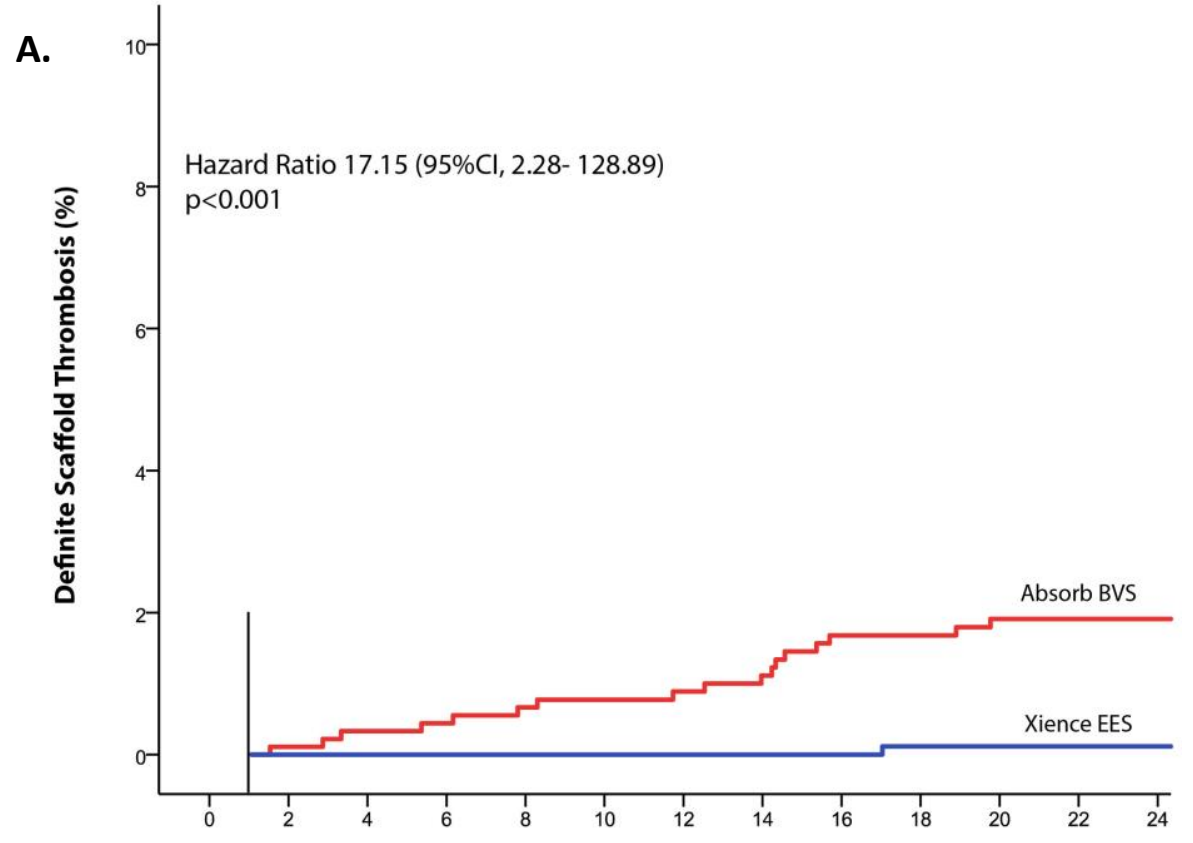

Months since index procedure
B.

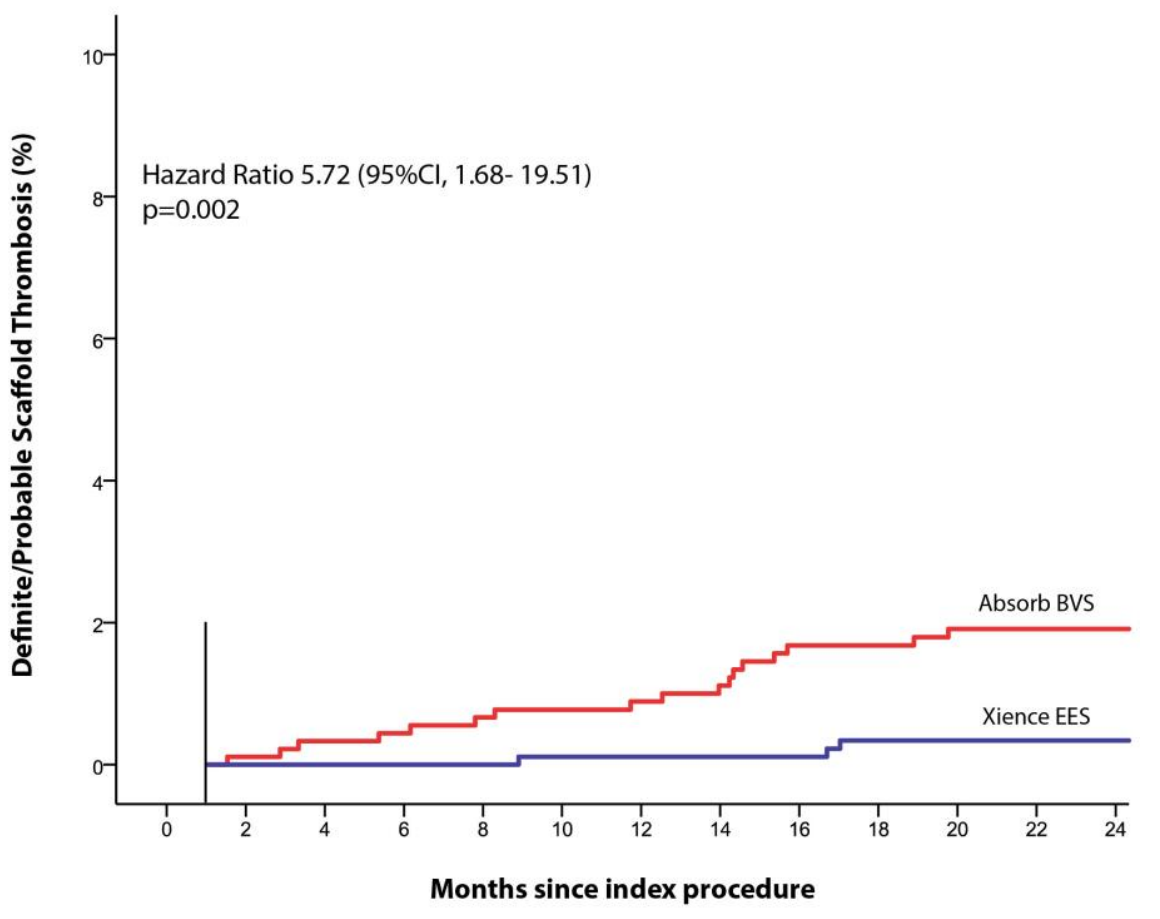


Supplementary Figure 3. Subgroup analysis of definite or probable device thrombosis at complete 2-year follow-up.

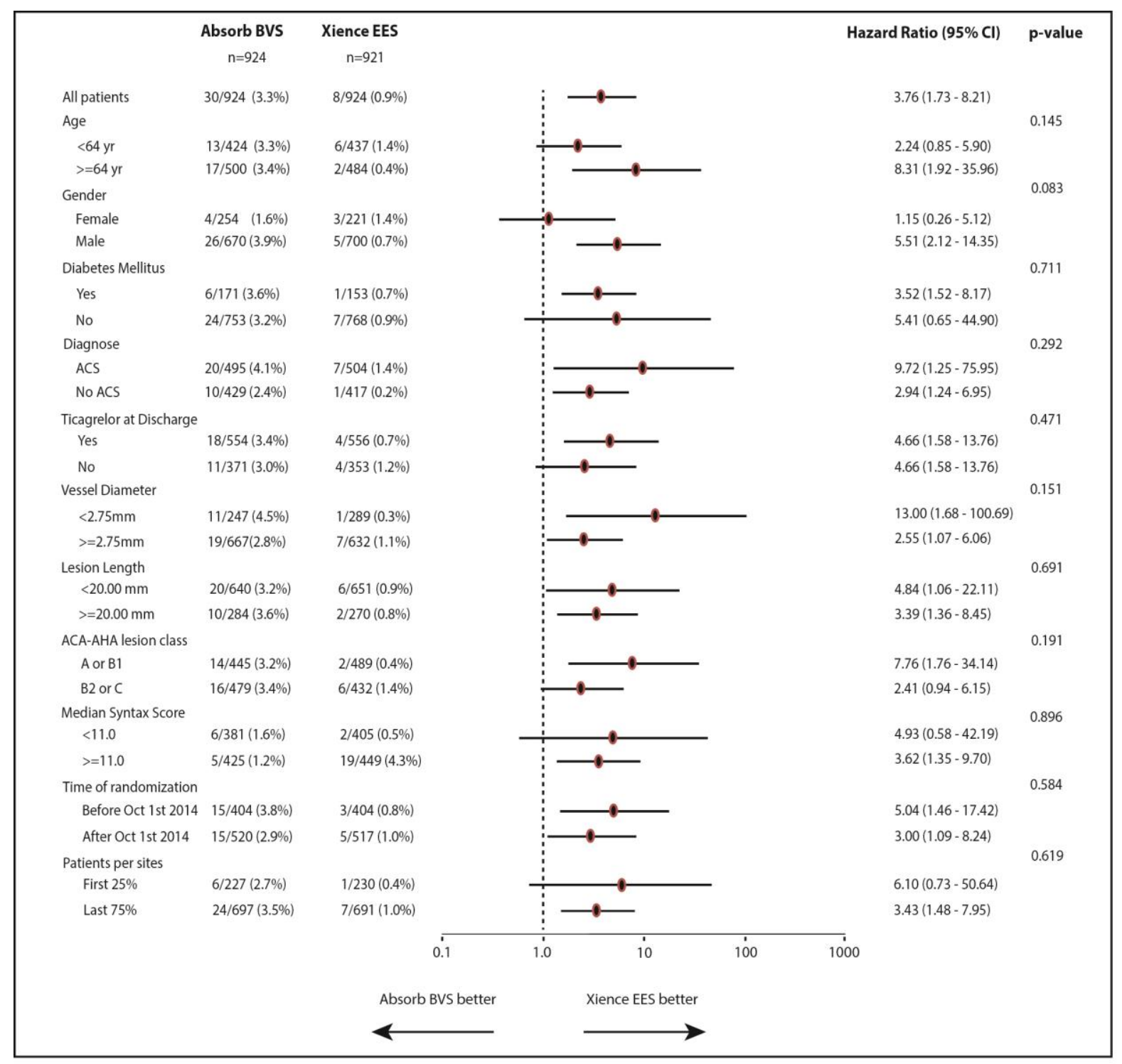




\begin{tabular}{|c|c|c|c|c|}
\hline \multirow{2}{*}{ Target lesion measures ${ }^{*}$} & \multicolumn{2}{|c|}{$\begin{array}{l}\text { Absorb BVS } \\
\text { group }\end{array}$} & \multicolumn{2}{|c|}{$\begin{array}{l}\text { XIENCE EES } \\
\text { group }\end{array}$} \\
\hline & & & & \\
\hline Total no. & \multicolumn{2}{|c|}{1,237} & \multicolumn{2}{|c|}{1,209} \\
\hline \multicolumn{5}{|l|}{ Coronary artery location - no. (\%) } \\
\hline Left main & 7 & $(6 \%)$ & 8 & $(0.7 \%)$ \\
\hline Left anterior descending & 526 & $(42 \%)$ & 528 & $(44 \%)$ \\
\hline Left circumflex & 297 & $(24 \%)$ & 318 & $(26 \%)$ \\
\hline Right & 401 & $(32 \%)$ & 348 & $(29 \%)$ \\
\hline Arterial bypass graft & 2 & $(0.2 \%)$ & 0 & $(0.0 \%)$ \\
\hline Venous bypass graft & 4 & $(0.3 \%)$ & 7 & $(0.6 \%)$ \\
\hline \multicolumn{5}{|l|}{ AHA/ACC lesion type - no./total no. of target lesions (\%) } \\
\hline A & $123 / 1,233$ & $(10 \%)$ & $124 / 1,206$ & $(10 \%)$ \\
\hline B1 & $437 / 1,233$ & $(35 \%)$ & $467 / 1,206$ & $(39 \%)$ \\
\hline B2 & $439 / 1,233$ & $(36 \%)$ & $415 / 1,206$ & $(34 \%)$ \\
\hline $\mathrm{C}$ & $234 / 1,233$ & $(19 \%)$ & $200 / 1,206$ & $(17 \%)$ \\
\hline Bifurcation - no. (\%) & 67 & $(5 \%)$ & 74 & $(6 \%)$ \\
\hline Chronic total occlusion - no. (\%) & 54 & $(4 \%)$ & 39 & $(3 \%)$ \\
\hline Moderately or severely calcified - no. (\%) & 368 & $(30 \%)$ & 336 & $(28 \%)$ \\
\hline Thrombus present - no. (\%) & 164 & $(13 \%)$ & 162 & $(13 \%)$ \\
\hline Ostial - no. (\%) & $69 / 1,235$ & $(6 \%)$ & 76 & $(6.3 \%)$ \\
\hline Lesion length $>20 \mathrm{~mm}$ " - no. (\%) & 389 & $(31 \%)$ & 324 & $(27 \%)$ \\
\hline Reference vessel diameter $\leq 2.75 \mathrm{~mm}$ " no./total no. of target lesions (\%) & $285 / 1,233$ & $(23 \%)$ & $338 / 1,207$ & $(28 \%)$ \\
\hline Lesion length, $\mathrm{mm}$ " & 19.1 & \pm 9.0 & 18.8 & \pm 9.5 \\
\hline Reference vessel diameter, $\mathrm{mm}$ " & 3.07 & \pm 0.41 & 3.03 & \pm 0.43 \\
\hline
\end{tabular}


Supplementary Table 2. Descriptive characteristics of cases of definite device thrombosis.

\begin{tabular}{|c|c|c|c|c|c|c|c|c|c|c|c|c|c|}
\hline Case & Group & $\begin{array}{l}\text { Initial PCI } \\
\text { indication }\end{array}$ & $\begin{array}{l}\text { Treated } \\
\text { vessel }\end{array}$ & $\begin{array}{l}\text { Lesion } \\
\text { type }\end{array}$ & $\begin{array}{c}\text { Ref size } \\
(\mathrm{mm})\end{array}$ & $\begin{array}{l}\text { Predilatation } \\
\text { (atm) }\end{array}$ & $\begin{array}{l}\text { Stent size } \\
\text { (atm) }\end{array}$ & $\begin{array}{c}\text { Post- } \\
\text { dilatation } \\
\text { (atm) }\end{array}$ & $\begin{array}{l}\text { Initial DAPT } \\
\text { therapy }\end{array}$ & $\begin{array}{l}\text { Days } \\
\text { to ST }\end{array}$ & $\begin{array}{c}\text { DAPT therapy } \\
\text { time of ST }\end{array}$ & $\begin{array}{l}\text { Clinical } \\
\text { outcome } \\
\text { (worst) }\end{array}$ & Patients note \\
\hline 1 & Absorb BVS & STEMI & Mid RCA & B2 & $4.0 \times 15$ & $3.0 \times 15(12)$ & $3.5 \times 18(13)$ & $4.0 x 12(13)$ & $\begin{array}{c}\text { ASA } \\
\text { Ticagrelor }\end{array}$ & 0 & $\begin{array}{c}\text { ASA } \\
\text { Ticagrelor }\end{array}$ & $\begin{array}{l}\text { Myocardial } \\
\text { infarction }\end{array}$ & $\begin{array}{c}\text { Dissection distal } \\
\text { of stent } \\
\text { (OCT) }\end{array}$ \\
\hline 2 & Absorb BVS & STEMI & Prox LAD & B2 & $3.5 \times 18$ & $3.5 \times 20(6)$ & $3.5 \times 18(14)$ & $3.5 \times 12(20)$ & $\begin{array}{c}\text { ASA } \\
\text { Ticagrelor }\end{array}$ & 1 & $\begin{array}{c}\text { ASA } \\
\text { Ticagrelor }\end{array}$ & $\begin{array}{l}\text { Myocardial } \\
\text { infarction }\end{array}$ & $\begin{array}{c}\text { Distal rdge } \\
\text { dissection (OCT) }\end{array}$ \\
\hline 3 & Absorb BVS & AP & Mid RCA & B2 & $3.0 \times 15$ & $3.0 \times 15(10)$ & $3.5 \times 18(14)$ & $4.0 \times 12(14)$ & $\begin{array}{c}\text { ASA } \\
\text { Clopidogrel }\end{array}$ & 2 & $\begin{array}{c}\text { ASA } \\
\text { Clopidogrel }\end{array}$ & $\begin{array}{l}\text { Myocardial } \\
\text { infarction }\end{array}$ & $\begin{array}{l}\text { Malapposition } \\
\text { stent } \\
\text { (OCT) }\end{array}$ \\
\hline 4 & Absorb BVS & AP & Mid RCA & C & $3.0 \times 46$ & $2.5 \times 20(16)$ & $\begin{array}{l}3.0 \times 28(12) \\
3.0 \times 18(14)\end{array}$ & $3.0 \times 20(18)$ & $\begin{array}{c}\text { ASA } \\
\text { Clopidogrel }\end{array}$ & 3 & $\begin{array}{c}\text { ASA } \\
\text { Clopidogrel }\end{array}$ & $\begin{array}{l}\text { Myocardial } \\
\text { infarction }\end{array}$ & \\
\hline 5 & Absorb BVS & STEMI & Prox LAD & C & $3.5 \times 21$ & $2.0 \times 12(12)$ & $\begin{array}{l}3.0 \times 15(14) \\
3.5 \times 12(16)\end{array}$ & $3.75 \times 15(22)$ & $\begin{array}{c}\text { ASA } \\
\text { Clopidogrel }\end{array}$ & 4 & $\begin{array}{c}\text { ASA } \\
\text { Clopidogrel }\end{array}$ & $\begin{array}{l}\text { Myocardial } \\
\text { infarction }\end{array}$ & \\
\hline 6 & Absorb BVS & AP & Distal RcX & B2 & $2.5 \times 28$ & $2.5 \times 20(10)$ & $2.5 \times 28(10)$ & $2.5 \times 20(14)$ & $\begin{array}{c}\text { ASA } \\
\text { Clopidogrel }\end{array}$ & 5 & $\begin{array}{c}\text { ASA } \\
\text { Clopidogrel }\end{array}$ & $\begin{array}{l}\text { Myocardial } \\
\text { infarction }\end{array}$ & $\begin{array}{c}\text { Possible low } \\
\text { therapy } \\
\text { compliance }\end{array}$ \\
\hline 7 & Absorb BVS & $\begin{array}{c}\text { Stabilised } \\
\text { STEMI }\end{array}$ & Prox RCA & C & $3.0 \times 30$ & $\begin{array}{l}3.5 \times 15(12) \\
\text { Rotablation }\end{array}$ & $\begin{array}{l}3.5 \times 18(14) \\
3.5 \times 18(14)\end{array}$ & $3.5 \times 15$ (14) & $\begin{array}{c}\text { ASA } \\
\text { Ticagrelor }\end{array}$ & 6 & ASA & $\begin{array}{l}\text { Myocardial } \\
\text { infarction }\end{array}$ & $\begin{array}{l}\text { Patient forgot to } \\
\text { take Ticagrelor }\end{array}$ \\
\hline 8 & Absorb BVS & NSTEMI & Prox LAD & B2 & $2.5 \times 15$ & $2.5 \times 15(\mathrm{UN})$ & $2.5 \times 18(10)$ & $3.0 \times 12(12)$ & $\begin{array}{c}\text { ASA } \\
\text { Ticagrelor }\end{array}$ & 11 & $\begin{array}{c}\text { ASA } \\
\text { Ticagrelor }\end{array}$ & $\begin{array}{l}\text { Myocardial } \\
\text { infarction }\end{array}$ & \\
\hline \multirow[b]{2}{*}{9} & \multirow[b]{2}{*}{ Absorb BVS } & \multirow[b]{2}{*}{ STEMI } & Prox LAD & C & $3.0 \times 25$ & $2.5 \times 20(8)$ & $3.0 \times 28(10)$ & $3.5 \times 15(10)$ & \multirow[b]{2}{*}{$\begin{array}{c}\text { ASA } \\
\text { Ticagrelor }\end{array}$} & \multirow[b]{2}{*}{29} & & \multirow[b]{2}{*}{$\begin{array}{l}\text { Myocardial } \\
\text { infarction }\end{array}$} & \multirow[b]{2}{*}{$\begin{array}{l}\text { ST in both LAD } \\
\text { and RCA }\end{array}$} \\
\hline & & & $\begin{array}{l}\text { Distal RCA } \\
\text { Mid RCA } \\
\text { Mid RCA }\end{array}$ & $\begin{array}{l}\mathrm{C} \\
\mathrm{C} \\
\mathrm{C}\end{array}$ & $\begin{array}{l}2.7 \times 25 \\
2.7 \times 25 \\
2.7 \times 25\end{array}$ & $\begin{array}{l}3.5 \times 20(12) \\
2.5 \times 20(10) \\
3.5 \times 20(10)\end{array}$ & $\begin{array}{l}2.5 \times 28(14) \\
3.0 \times 28(14) \\
2.5 \times 28(14)\end{array}$ & $\begin{array}{l}\text { No } \\
\text { No } \\
\text { No }\end{array}$ & & & $\begin{array}{c}\text { ASA } \\
\text { Ticagrelor }\end{array}$ & & \\
\hline 10 & Absorb BVS & NSTEMI & $\begin{array}{l}\text { Mid LAD } \\
\text { Prox LAD }\end{array}$ & B2 & $3.0 \times 45$ & $2.5 \times 20(14)$ & $\begin{array}{l}2.5 \times 23(16) \\
3.0 \times 28(18) \\
3.5 \times 18(18)\end{array}$ & $\begin{array}{l}4.0 \times 15(18) \\
4.0 \times 15(18) \\
\end{array}$ & $\begin{array}{c}\text { ASA } \\
\text { Ticagrelor } \\
\text { OAC }\end{array}$ & 46 & $\begin{array}{c}\text { Clopidogrel } \\
\text { OAC }\end{array}$ & $\begin{array}{l}\text { Myocardial } \\
\text { infarction }\end{array}$ & $\begin{array}{l}\text { Malapposition } \\
\text { stent } \\
\text { (OCT) }\end{array}$ \\
\hline 11 & Absorb BVS & UAP & Mid LAD & B1 & $3.0 \times 12$ & $2.5 \times 15(10)$ & $3.0 \times 18(12)$ & No & $\begin{array}{c}\text { ASA } \\
\text { Ticagrelor }\end{array}$ & 86 & $\begin{array}{c}\text { ASA } \\
\text { Ticagrelor }\end{array}$ & $\begin{array}{l}\text { Myocardial } \\
\text { infarction }\end{array}$ & $\begin{array}{c}\text { Interaction } \\
\text { Ticagrelor and } \\
\text { HIV medication }\end{array}$ \\
\hline 12 & Absorb BVS & NSTEMI & Prox RCA & B1 & $3.5 \times 10$ & $3.0 \times 15(12)$ & $3.5 \times 12(14)$ & $3.5 \times 8(22)$ & $\begin{array}{c}\text { ASA } \\
\text { Clopidogrel } \\
\text { OAC }\end{array}$ & 100 & $\begin{array}{l}\text { Clopidogrel } \\
\text { OAC }\end{array}$ & $\begin{array}{l}\text { Non-fatal MI } \\
\text { followed by } \\
\text { cardiac death }\end{array}$ & \\
\hline
\end{tabular}




\begin{tabular}{|c|c|c|c|c|c|c|c|c|c|c|c|c|c|}
\hline 13 & Absorb BVS & UAP & Mid LAD & B1 & $15 \times 3.5$ & $2.0 \times 15(18)$ & $3.5 \times 18(10)$ & $3.5 \times 15(16)$ & $\begin{array}{c}\text { ASA } \\
\text { Ticagrelor }\end{array}$ & 161 & None & $\begin{array}{l}\text { Myocardial } \\
\text { infarction }\end{array}$ & $\begin{array}{l}\text { DAPT cessation } \\
\text { during surgery }\end{array}$ \\
\hline 15 & Absorb BVS & NSTEMI & Prox RcX & B2 & $3.0 \times 28$ & $2.5 \times 15(12)$ & $3.0 \times 28(14)$ & $3.5 \times 15(14)$ & $\begin{array}{c}\text { ASA } \\
\text { Ticagrelor }\end{array}$ & 185 & None & $\begin{array}{l}\text { Myocardial } \\
\text { infarction }\end{array}$ & $\begin{array}{l}\text { DAPT cessation } \\
\text { during surgery }\end{array}$ \\
\hline 16 & Absorb BVS & STEMI & Mid LAD & B1 & $2.5 \times 23$ & $2.0 \times 20(14)$ & $2.5 \times 23(14)$ & $2.5 \times 15(18)$ & $\begin{array}{c}\text { ASA } \\
\text { Ticagrelor }\end{array}$ & 234 & $\begin{array}{c}\text { ASA } \\
\text { Ticagrelor }\end{array}$ & $\begin{array}{l}\text { Myocardial } \\
\text { infarction }\end{array}$ & \\
\hline 17 & Absorb BVS & AP & RcX, OM & B1 & $2.5 \times 12$ & $2.5 \times 15(8)$ & $2.5 \times 18(6)$ & No & $\begin{array}{c}\text { ASA } \\
\text { Ticagrelor }\end{array}$ & 249 & ASA & $\begin{array}{l}\text { Myocardial } \\
\text { infarction }\end{array}$ & $\begin{array}{c}\text { History of low } \\
\text { therapy } \\
\text { compliance }\end{array}$ \\
\hline 18 & Absorb BVS & NSTEMI & Prox RcX & B2 & $2.5 \times 15$ & $\begin{array}{c}2.5 \times 15(8) \\
\text { Rotablation } \\
\text { Rotablation }\end{array}$ & $2.5 \times 18(14)$ & $2.75 \times 15(16)$ & $\begin{array}{c}\text { ASA } \\
\text { Ticagrelor } \\
\text { Ticagrelor }\end{array}$ & 352 & ASA & $\begin{array}{l}\text { Myocardial } \\
\text { infarction }\end{array}$ & $\begin{array}{c}\text { Dissection after } \\
\text { stent } \\
\text { implantation } \\
\text { (Angio) } \\
\end{array}$ \\
\hline 19 & Absorb BVS & AP & $\begin{array}{c}\text { Mid RCA } \\
\text { Distal RCA }\end{array}$ & $\begin{array}{l}\text { B2 } \\
\text { B2 }\end{array}$ & $\begin{array}{l}3.5 \times 25 \\
3.0 \times 15\end{array}$ & $\begin{array}{l}2.5 \times 20(12) \\
2.5 \times 20(12)\end{array}$ & $\begin{array}{l}3.5 \times 28(12) \\
3.0 \times 18(14)\end{array}$ & $\begin{array}{c}4.0 \times 15(10) \\
\text { No }\end{array}$ & $\begin{array}{c}\text { ASA } \\
\text { Ticagrelor }\end{array}$ & 376 & ASA & $\begin{array}{l}\text { Myocardial } \\
\text { infarction }\end{array}$ & $\begin{array}{l}\text { Malapposition } \\
\text { distal stent } \\
\text { (OCT) }\end{array}$ \\
\hline 20 & Absorb BVS & STEMI & Distal RCA & B2 & $3.0 \times 24$ & $2.0 \times 20(10)$ & $3.0 \times 27(8)$ & $3.5 \times 15(18)$ & $\begin{array}{c}\text { ASA } \\
\text { Ticagrelor }\end{array}$ & 419 & ASA & $\begin{array}{l}\text { Myocardial } \\
\text { infarction }\end{array}$ & \\
\hline 21 & Absorb BVS & AP & Dist RcX & B1 & $3.0 \times 10$ & $3.0 \times 15(18)$ & $3.0 \times 18(12)$ & No & $\begin{array}{c}\text { ASA } \\
\text { Ticagrelor } \\
\text { OAC }\end{array}$ & 427 & OAC only & $\begin{array}{l}\text { Myocardial } \\
\text { infarction }\end{array}$ & \\
\hline 22 & Absorb BVS & STEMI & Mid RCA & B2 & $3.5 \times 23$ & $3.5 \times 20(10)$ & $3.5 \times 28(12)$ & $3.5 \times 15(12)$ & $\begin{array}{c}\text { ASA } \\
\text { Prasugrel } \\
\text { OAC } \\
\text { ASA stop } \\
\text { after } 3 \\
\text { months } \\
\end{array}$ & 430 & None & $\begin{array}{l}\text { Non-fatal MI } \\
\text { followed by } \\
\text { cardiac death }\end{array}$ & $\begin{array}{l}\text { OAC cessation } \\
\text { during surgery } \\
\text { (Clexane) }\end{array}$ \\
\hline 23 & Absorb BVS & Angio-driven & $\begin{array}{l}\text { Prox RCA } \\
\text { Prox RcX }\end{array}$ & $\begin{array}{l}\text { B1 } \\
\mathrm{A}\end{array}$ & $\begin{array}{l}4.0 \times 16 \\
3.5 \times 12 \\
\end{array}$ & $\begin{array}{l}3.0 \times 20(16) \\
3.0 \times 12(14)\end{array}$ & $\begin{array}{l}3.5 \times 28(16) \\
3.0 \times 23(16)\end{array}$ & $\begin{array}{l}4.0 \times 20(12) \\
3.5 \times 40(16)\end{array}$ & $\begin{array}{c}\text { ASA } \\
\text { Clopidogrel }\end{array}$ & 437 & Unknown & $\begin{array}{l}\text { Myocardial } \\
\text { infarction }\end{array}$ & \\
\hline 23 & Absorb BVS & $\begin{array}{l}\text { STEMI } \\
\text { Staged } \\
\end{array}$ & $\begin{array}{l}\text { Prox RCA } \\
\text { Prox RcX } \\
\end{array}$ & $\begin{array}{l}\mathrm{B} 2 \\
\mathrm{~B} 1 \\
\end{array}$ & $\begin{array}{l}2.5 \times 15 \\
3.0 \times 12 \\
\end{array}$ & $\begin{array}{l}2.5 \times 15(10) \\
3.0 \times 15(10) \\
\end{array}$ & $\begin{array}{l}3.0 \times 18(12) \\
3.0 \times 18(14) \\
\end{array}$ & $\begin{array}{l}\text { No } \\
\text { No } \\
\end{array}$ & $\begin{array}{c}\text { ASA } \\
\text { Ticagrelor }\end{array}$ & 461 & ASA & $\begin{array}{l}\text { Myocardial } \\
\text { infarction }\end{array}$ & \\
\hline 24 & $\begin{array}{l}\text { Absorb BVS } \\
\text { Absorb BVS } \\
\text { XIENCE EES }\end{array}$ & AP & $\begin{array}{l}\text { Distal LAD } \\
\text { Prox LAD } \\
\text { RcX, OM }\end{array}$ & $\begin{array}{c}\text { B1 } \\
\text { A } \\
\text { B1 }\end{array}$ & $\begin{array}{c}3.0 \times 8 \\
3.5 \times 12 \\
2.5 \times 12\end{array}$ & $\begin{array}{l}2.5 \times 28(14) \\
3.0 \times 12(14) \\
2.5 \times 15(10)\end{array}$ & $\begin{array}{l}3.0 \times 28(14) \\
3.5 \times 12(14) \\
2.5 \times 12(12)\end{array}$ & $\begin{array}{c}3.0 \times 28(14) \\
3.5 \times 14(14) \\
\mathrm{No}\end{array}$ & $\begin{array}{c}\text { ASA } \\
\text { Ticagrelor }\end{array}$ & 471 & $\begin{array}{c}\text { ASA } \\
\text { Ticagrelor }\end{array}$ & $\begin{array}{l}\text { Myocardial } \\
\text { infarction }\end{array}$ & \\
\hline
\end{tabular}




\begin{tabular}{|c|c|c|c|c|c|c|c|c|c|c|c|c|c|}
\hline 25 & Absorb BVS & STEMI & Prox RCA & $C$ & $3.5 \times 18$ & $3.0 \times 15(12)$ & $3.5 \times 23(16)$ & $4.0 \times 20(16)$ & $\begin{array}{c}\text { ASA } \\
\text { Prasugrel }\end{array}$ & 567 & ASA & $\begin{array}{l}\text { Myocardial } \\
\text { infarction }\end{array}$ & \\
\hline 26 & Absorb BVS & STEMI & Mid RCA & B2 & $3.0 \times 25$ & $3.0 \times 15(12)$ & $3.0 \times 28(10)$ & $2.25 \times 20(13)$ & $\begin{array}{c}\text { ASA } \\
\text { Ticagrelor }\end{array}$ & 593 & ASA & $\begin{array}{l}\text { Myocardial } \\
\text { infarction }\end{array}$ & \\
\hline 27 & Absorb BVS & STEMI & Prox LAD & $C$ & $3.5 \times 21$ & $2.5 \times 20(10)$ & $3.5 \times 23(18)$ & $3.5 \times 15(18)$ & $\begin{array}{c}\text { ASA } \\
\text { Ticagrelor }\end{array}$ & 733 & ASA & $\begin{array}{l}\text { Myocardial } \\
\text { infarction }\end{array}$ & $\begin{array}{l}\text { Patient refused } \\
\text { re-start of DAPT }\end{array}$ \\
\hline 28 & Absorb BVS & NSTEMI & AO-OM graft & B2 & $3.0 \times 18$ & $2.0 \times 15(12)$ & $3.0 \times 18(10)$ & $3.0 \times 12(14)$ & $\begin{array}{c}\text { ASA } \\
\text { Clopidrogrel }\end{array}$ & & ASA & $\begin{array}{l}\text { Myocardial } \\
\text { infarction }\end{array}$ & \\
\hline 29 & Absorb BVS & AP & Prox LAD & $A$ & $3.5 \times 8$ & $3.0 \times 15(12)$ & $2.5 \times 12(12)$ & $3.5 \times 8(20)$ & $\begin{array}{c}\text { ASA } \\
\text { Clopidrogrel }\end{array}$ & 817 & ASA & $\begin{array}{l}\text { Myocardial } \\
\text { infarction }\end{array}$ & $\begin{array}{c}\text { OCT } \\
\text { malapposed } \\
\text { non-covered } \\
\text { struts distally }\end{array}$ \\
\hline 30 & Absorb BVS & NSTEMI & RcX, OM & B1 & $2.5 \times 10$ & $2.5 \times 15(20)$ & $2.5 \times 12(16)$ & $2.75 \times 15(18)$ & $\begin{array}{c}\text { ASA } \\
\text { Ticagrelor }\end{array}$ & 825 & ASA & $\begin{array}{l}\text { Myocardial } \\
\text { infarction }\end{array}$ & \\
\hline \multirow[t]{2}{*}{31} & Absorb BVS & $\begin{array}{l}\text { Stabilised } \\
\text { STEMI }\end{array}$ & Distal LAD & $C$ & $2.5 \times 45$ & $2.5 \times 30(12)$ & $\begin{array}{l}2.5 \times 28(16) \\
2.5 \times 28(16)\end{array}$ & No & $\begin{array}{c}\text { ASA } \\
\text { Ticagrelor }\end{array}$ & 1,277 & Unknown & $\begin{array}{l}\text { Myocardial } \\
\text { infarction }\end{array}$ & ST in LAD \\
\hline & & & First diagonal & B2 & $3.5 \times 12$ & $3.5 \times 15(16)$ & $3.5 \times 12(14)$ & $4.0 \times 9$ (14) & & & & & \\
\hline
\end{tabular}




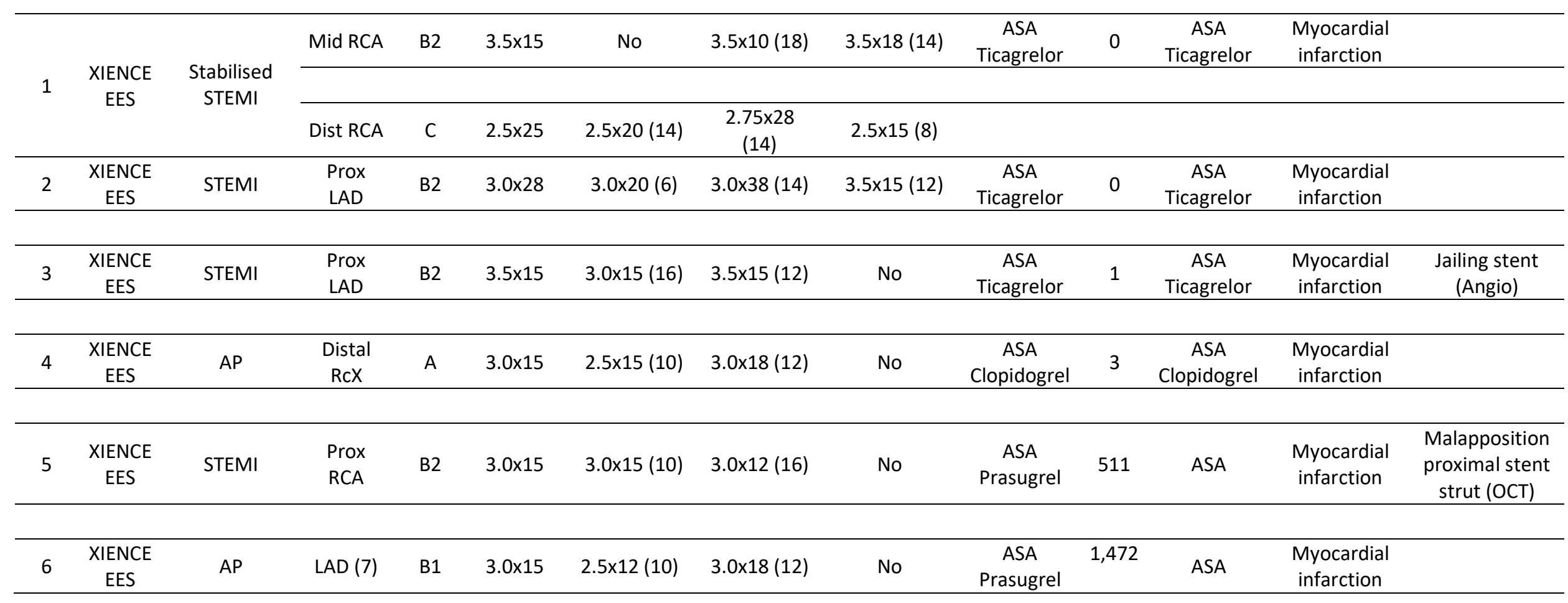




\begin{tabular}{|c|c|c|c|c|c|c|c|}
\hline \multicolumn{8}{|c|}{ Supplementary Table 3. Safety and efficacy outcomes at 1-year follow-up\$. } \\
\hline & \multirow{2}{*}{\multicolumn{2}{|c|}{$\begin{array}{c}\text { Absorb BVS } \\
\text { group } \\
924\end{array}$}} & \multirow{2}{*}{\multicolumn{2}{|c|}{$\begin{array}{c}\text { XIENCE EES } \\
\text { group } \\
921\end{array}$}} & \multicolumn{2}{|c|}{ Hazard ratio $(95 \% \mathrm{Cl})$} & \multirow[t]{2}{*}{$p$-value } \\
\hline & & & & & & & \\
\hline \multicolumn{8}{|l|}{ Clinical events } \\
\hline All-cause death & 19 & $(2.1)$ & 23 & $(2.5)$ & 0.82 & $(0.45-1.51)$ & 0.528 \\
\hline Cardiac & 12 & $(1.3)$ & 11 & $(1.2)$ & 1.09 & $(0.48-2.47)$ & 0.841 \\
\hline Cardiovascular & 15 & $(1.6)$ & 12 & $(1.3)$ & 1.25 & $(0.58-2.66)$ & 0.569 \\
\hline Non-cardiovascular & 4 & $(0.4)$ & 11 & $(1.2)$ & 0.36 & $(0.11-1.14)$ & 0.069 \\
\hline All myocardial infarction & 40 & $(4.4)$ & 28 & $(3.1)$ & 1.43 & $(0.89-2.32)$ & 0.141 \\
\hline Target vessel & 34 & $(3.7)$ & 20 & $(2.2)$ & 1.71 & $(0.98-2.96)$ & 0.055 \\
\hline During index procedure & 9 & $(1.0)$ & 6 & $(0.7)$ & 1.50 & $(0.53-4.20)$ & 0.441 \\
\hline Not during index procedure & 25 & $(2.7)$ & 14 & $(1.5)$ & 1.79 & $(0.93-3.44)$ & 0.077 \\
\hline Non-target vessel & 7 & $(0.8)$ & 8 & $(0.9)$ & 0.87 & $(0.32-2.40)$ & 0.790 \\
\hline Death or myocardial infarction & 56 & $(6.1)$ & 47 & $(5.1)$ & 1.20 & $(0.81-1.76)$ & 0.363 \\
\hline Any revascularisation & 77 & $(8.4)$ & 67 & $(7.3)$ & 1.15 & $(0.83-1.59)$ & 0.414 \\
\hline Target vessel & 48 & $(5.2)$ & 38 & $(4.2)$ & 1.27 & $(0.83-1.94)$ & 0.278 \\
\hline Target lesion & 38 & $(4.2)$ & 27 & $(3.0)$ & 1.41 & $(0.86-2.31)$ & 0.171 \\
\hline Device thrombosis-related & 16 & $(1.7)$ & 4 & $(0.4)$ & 4.00 & (1.34-11.96) & 0.007 \\
\hline Device stenosis-related & 22 & $(2.4)$ & 23 & $(2.5)$ & 0.89 & $(0.58-1.36)$ & 0.869 \\
\hline Non-target lesion & 11 & $(1.2)$ & 11 & $(1.2)$ & 1.00 & $(0.43-2.30)$ & 0.996 \\
\hline Non-target vessel & 36 & (3.9) & 36 & (3.9) & & & \\
\hline \multicolumn{8}{|l|}{ Composite endpoints } \\
\hline Target vessel failure* & 70 & $(7.6)$ & 56 & $(6.1)$ & 1.26 & $(0.88-1.78)$ & 0.204 \\
\hline Target lesion failure ${ }^{\#}$ & 60 & $(6.5)$ & 48 & $(5.3)$ & 1.25 & $(0.86-1.83)$ & 0.243 \\
\hline Patient-oriented composite endpoint ${ }^{¥}$ & 107 & $(11.6)$ & 97 & $(10.6)$ & 1.09 & $(0.88-1.34)$ & 0.481 \\
\hline \multicolumn{8}{|l|}{ Device thrombosis } \\
\hline Any device thrombosis & 23 & $(2.5)$ & 10 & $(1.1)$ & 2.30 & $(1.10-4.84)$ & 0.023 \\
\hline Definite & 17 & (1.9) & 4 & $(0.4)$ & 4.25 & $(1.43-12.63)$ & 0.005 \\
\hline Probable & 4 & $(0.4)$ & 2 & $(0.2)$ & 1.99 & $(0.37-10.88)$ & 0.417 \\
\hline Possible & 2 & $(0.2)$ & 4 & $(0.4)$ & 0.50 & $(0.09-2.72)$ & 0.410 \\
\hline Definite/probable & 21 & $(2.3)$ & 6 & $(0.7)$ & 3.5 & $(1.41-8.68)$ & 0.004 \\
\hline$\leq 24 \mathrm{~h}$ (acute) & 3 & & 3 & & & & \\
\hline$>24 \mathrm{~h}$ to $30 \mathrm{~d}$ (subacute) & 10 & & 2 & & & & \\
\hline $31 \mathrm{~d}$ to 1 y (late) & 8 & & 1 & & & & \\
\hline
\end{tabular}




\begin{tabular}{|c|c|c|c|c|c|c|c|}
\hline \multicolumn{8}{|c|}{ Supplementary Table 4. Safety and efficacy outcomes between $1^{\text {st }}$ and $2^{\text {nd }}$ year follow-up\$. } \\
\hline & \multicolumn{2}{|l|}{$\begin{array}{c}\text { Absorb BVS } \\
\text { group }\end{array}$} & \multicolumn{2}{|c|}{$\begin{array}{l}\text { XIENCE EES } \\
\text { group }\end{array}$} & \multicolumn{2}{|c|}{ Hazard ratio $(95 \% \mathrm{Cl})$} & \multirow[t]{2}{*}{$p$-value } \\
\hline & 924 & & 921 & & & & \\
\hline \multicolumn{8}{|l|}{ Clinical events } \\
\hline All-cause death & $11 / 896$ & $(1.3)$ & $14 / 890$ & $(1.6)$ & 0.79 & $(0.36-1.73)$ & 0.547 \\
\hline Cardiac & 5 & (0.6) & 9 & $(1.0)$ & 0.56 & $(0.19-1.66)$ & 0.285 \\
\hline Cardiovascular & 6 & (0.7) & 10 & $(1.1)$ & 0.60 & $(0.22-1.65)$ & 0.317 \\
\hline Non-cardiovascular & 5 & $(0.6)$ & 4 & $(0.5)$ & 1.25 & $(0.34-4.65)$ & 0.741 \\
\hline All myocardial infarction & $19 / 859$ & (2.2) & $9 / 867$ & $(1.0)$ & 2.15 & $(0.97-4.74)$ & 0.053 \\
\hline Target vessel & 12 & (1.4) & 8 & $(0.9)$ & 1.52 & $(0.62-3.72)$ & 0.356 \\
\hline Non-target vessel & 7 & $(0.8)$ & 1 & $(0.001)$ & 7.11 & $(0.88-57.79)$ & 0.032 \\
\hline Death or myocardial infarction & $27 / 859$ & (3.2) & $23 / 867$ & $(2.7)$ & 1.20 & (0.69-2.09) & 0.529 \\
\hline Any revascularisation & $38 / 821$ & (4.7) & $31 / 825$ & (3.8) & 1.24 & $(0.77-2.00)$ & 0.369 \\
\hline Target vessel & 24 & (3.0) & 23 & $(2.8)$ & 1.05 & (0.59-1.87) & 0.859 \\
\hline Target lesion & 19 & (2.4) & 15 & (1.8) & 1.28 & $(0.65-2.52)$ & 0.473 \\
\hline Device thrombosis-related & 7 & (0.9) & 1 & $(0.001)$ & 7.07 & $(0.87-57.45)$ & 0.033 \\
\hline Device stenosis-related & 12 & (1.5) & 14 & $(1.7)$ & 0.86 & $(0.40-1.87)$ & 0.707 \\
\hline Non-target lesion & 7 & (0.9) & 8 & (1.0) & 0.88 & $(0.32-2.43)$ & 0.808 \\
\hline Non-target vessel & 19 & (2.4) & 9 & (1.1) & 2.15 & $(0.97-4.74)$ & 0.053 \\
\hline \multicolumn{8}{|l|}{ Composite endpoints } \\
\hline Target vessel failure* & $30 / 838$ & (3.7) & $34 / 846$ & (4.1) & 0.90 & $(0.55-1.46)$ & 0.661 \\
\hline Target lesion failure ${ }^{\#}$ & $28 / 848$ & (3.4) & $27 / 845$ & $(3.2)$ & 1.05 & $(0.62-1.79)$ & 0.851 \\
\hline Patient-oriented composite endpoint ${ }^{*}$ & $48 / 809$ & (6.1) & $43 / 817$ & (5.3) & 1.07 & $(0.78-1.47)$ & 0.534 \\
\hline \multicolumn{8}{|l|}{ Device thrombosis } \\
\hline Any device thrombosis & $12 / 880$ & (1.4) & $8 / 886$ & $(0.9)$ & 1.52 & $(0.62-3.73)$ & 0.352 \\
\hline Definite & 9 & (1.0) & 1 & $(0.1)$ & & & \\
\hline Probable & 0 & $(0.0)$ & 1 & $(0.001)$ & 0.015 & $(0.000-148,382.68)$ & 0.319 \\
\hline Possible & 3 & $(0.4)$ & 6 & $(0.7)$ & 0.51 & $(0.13-2.03)$ & 0.329 \\
\hline Definite/probable & 9 & (1.0) & 2 & $(0.2)$ & 4.55 & $(0.98-21.06)$ & 0.033 \\
\hline
\end{tabular}




\begin{tabular}{|c|c|c|c|c|c|c|c|}
\hline \multicolumn{8}{|c|}{ Supplementary Table 5. Safety and efficacy outcomes in the "as treated" population at 2-year follow-up\$. } \\
\hline & \multirow{2}{*}{\multicolumn{2}{|c|}{$\begin{array}{c}\text { Absorb BVS } \\
\text { group } \\
\mathrm{N}=895\end{array}$}} & \multirow{2}{*}{\multicolumn{2}{|c|}{$\begin{array}{c}\text { XIENCE EES } \\
\text { group } \\
\mathrm{N}=919\end{array}$}} & \multicolumn{2}{|c|}{ Hazard ratio $(95 \% \mathrm{CI})$} & \multirow[t]{2}{*}{$p$-value } \\
\hline & & & & & & & \\
\hline \multicolumn{8}{|l|}{ Clinical events } \\
\hline All-cause death & 30 & (3.4) & 37 & $(4.1)$ & 0.83 & $(0.52-1.35)$ & 0.457 \\
\hline Cardiac & 17 & (1.9) & 20 & $(2.2)$ & 0.88 & $(0.46-1.67)$ & 0.684 \\
\hline Cardiovascular & 21 & (2.4) & 22 & (2.4) & 0.98 & (0.54-1.79) & 0.953 \\
\hline Non-cardiovascular & 9 & (1.0) & 15 & $(1.7)$ & 0.62 & $(0.27-1.41)$ & 0.247 \\
\hline All myocardial infarction & 58 & (6.6) & 37 & $(4.1)$ & 1.63 & $(1.08-2.46)$ & 0.019 \\
\hline Target vessel & 45 & (5.1) & 28 & (3.1) & 1.67 & $(1.04-2.67)$ & 0.032 \\
\hline During index procedure & 9 & (1.0) & 6 & $(0.7)$ & 1.54 & $(0.55-4.33)$ & 0.408 \\
\hline Not during index procedure & 36 & (4.1) & 22 & $(2.4)$ & 1.69 & $(1.00-2.88)$ & 0.049 \\
\hline Non-target vessel & 14 & (1.6) & 9 & $(1.0)$ & 1.60 & $(0.69-3.70)$ & 0.267 \\
\hline Death or myocardial infarction & 82 & (9.3) & 70 & $(7.3)$ & 1.22 & $(0.89-1.68)$ & 0.223 \\
\hline Any revascularisation & 112 & $(12.8)$ & 98 & (10.9) & 1.18 & $(0.90-1.55)$ & 0.227 \\
\hline Target vessel & 73 & $(8.4)$ & 63 & $(7.0)$ & 1.20 & $(0.86-1.68)$ & 0.285 \\
\hline Target lesion & 59 & (6.8) & 44 & (4.9) & 1.39 & $(0.94-2.05)$ & 0.097 \\
\hline Device thrombosis-related & 25 & (2.9) & 5 & $(0.5)$ & 5.17 & $(1.98-13.51)$ & $<0.001$ \\
\hline Device stenosis-related & 35 & (4.0) & 39 & (4.4) & 0.92 & $(0.58-1.45)$ & 0.723 \\
\hline Non-target lesion & 19 & (2.2) & 20 & (2.2) & 0.98 & $(0.52-1.83)$ & 0.943 \\
\hline Non-target vessel & 55 & (6.3) & 48 & (5.3) & 1.18 & $(0.80-1.73)$ & 0.414 \\
\hline \multicolumn{8}{|l|}{ Composite endpoints } \\
\hline Target vessel failure* & 98 & $(11.1)$ & 90 & $(10.0)$ & 1.13 & $(0.85-1.51)$ & 0.396 \\
\hline Target lesion failure ${ }^{\#}$ & 87 & (9.9) & 75 & $(8.3)$ & 1.20 & $(0.88-1.64)$ & 0.238 \\
\hline Patient-oriented composite endpoint ${ }^{¥}$ & 151 & $(17.1)$ & 140 & $(15.4)$ & 1.09 & $(0.89-1.35)$ & 0.336 \\
\hline \multicolumn{8}{|l|}{ Device thrombosis } \\
\hline Definite & 26 & (3.0) & 5 & $(0.5)$ & 5.38 & $(2.07-14.02)$ & $<0.001$ \\
\hline Probable & 4 & $(0.4)$ & 3 & $(0.3)$ & 1.37 & $(0.31-6.11)$ & 0.680 \\
\hline Possible & 5 & $(0.6)$ & 10 & (1.1) & 0.52 & $(0.18-1.51)$ & 0.218 \\
\hline Definite/probable device thrombosis & 30 & (3.4) & 8 & (0.7) & 3.88 & $(1.78-8.47)$ & $<0.001$ \\
\hline$\leq 24 \mathrm{~h}$ (acute) & 3 & & 3 & & & & \\
\hline$>24 \mathrm{~h}$ to $30 \mathrm{~d}$ (subacute) & 10 & & 2 & & & & \\
\hline $31 \mathrm{~d}$ to 1 y (late) & 8 & & 1 & & & & \\
\hline $1-2$ y (very late) & 9 & & 2 & & & & \\
\hline Any device thrombosis & 35 & $(4.0)$ & 18 & $(2.0)$ & 2.02 & $(1.14-3.57)$ & 0.013 \\
\hline
\end{tabular}




\begin{tabular}{|c|c|c|c|c|c|c|c|}
\hline \multicolumn{8}{|c|}{ Supplementary Table 6. Safety and efficacy outcomes per protocol treatment at 2-year follow-up $\$$. } \\
\hline & $\begin{array}{r}\text { Absorb } \\
\text { group } \\
\mathrm{N}=91\end{array}$ & & $\begin{array}{r}\text { XIENCE } \\
\text { group } \\
\mathrm{N}=920\end{array}$ & & \multicolumn{2}{|c|}{ Hazard ratio $(95 \% \mathrm{Cl})$} & $p$-value \\
\hline \multicolumn{8}{|l|}{ Clinical events } \\
\hline All-cause death & 30 & (3.3) & 37 & $(4.1)$ & 0.82 & $(0.50-1.32)$ & 0.406 \\
\hline Cardiac & 17 & (1.9) & 20 & $(2.2)$ & 0.86 & $(0.45-1.63)$ & 0.637 \\
\hline Cardiovascular & 21 & $(2.3)$ & 22 & $(2.4)$ & 0.96 & $(0.53-1.75)$ & 0.897 \\
\hline Non-cardiovascular & 9 & $(1.0)$ & 15 & $(1.7)$ & 0.60 & $(0.26-1.38)$ & 0.226 \\
\hline All myocardial infarction & 59 & $(6.6)$ & 37 & $(4.1)$ & 1.62 & $(1.08-2.45)$ & 0.020 \\
\hline Target vessel & 46 & $(5.1)$ & 28 & (3.1) & 1.67 & $(1.04-2.67)$ & 0.031 \\
\hline During index procedure & 9 & (1.0) & 6 & $(0.7)$ & 1.51 & $(0.54-4.24)$ & 0.431 \\
\hline Not during index procedure & 37 & $(4.1)$ & 22 & $(2.4)$ & 1.70 & $(1.01-2.89)$ & 0.045 \\
\hline Non-target vessel & 14 & $(1.6)$ & 9 & $(1.0)$ & 1.57 & $(0.68-3.62)$ & 0.290 \\
\hline Death or myocardial infarction & 72 & $(8.2)$ & 65 & $(7.4)$ & 1.13 & $(0.81-1.58)$ & 0.469 \\
\hline Any revascularisation & 115 & (12.9) & 98 & (10.9) & 1.19 & $(0.91-1.56)$ & 0.210 \\
\hline Target vessel & 74 & $(8.3)$ & 63 & $(7.0)$ & 1.19 & $(0.85-1.67)$ & 0.307 \\
\hline Target lesion & 59 & $(6.6)$ & 44 & $(4.9)$ & 1.36 & $(0.92-2.01)$ & 0.121 \\
\hline Device thrombosis-related & 25 & $(2.8)$ & 5 & $(0.5)$ & 5.06 & $(1.94-13.22)$ & $<0.001$ \\
\hline Device stenosis-related & 35 & (3.9) & 39 & $(4.4)$ & 0.90 & $(0.57-1.42)$ & 0.654 \\
\hline Non-target lesion & 20 & $(2.3)$ & 20 & $(2.2)$ & 1.01 & $(0.54-1.87)$ & 0.982 \\
\hline Non-target vessel & 58 & $(6.5)$ & 48 & $(5.3)$ & 1.21 & $(0.83-1.78)$ & 0.321 \\
\hline \multicolumn{8}{|l|}{ Composite endpoints } \\
\hline Target vessel failure ${ }^{*}$ & 100 & (11.1) & 90 & $(10.0)$ & 1.13 & $(0.85-1.50)$ & 0.399 \\
\hline Target lesion failure \# & 88 & $(9.8)$ & 75 & $(8.3)$ & 1.19 & $(0.88-1.62)$ & 0.263 \\
\hline Patient-oriented composite endpoint ${ }^{¥}$ & 155 & $(17.1)$ & 140 & $(15.0)$ & 1.09 & $(0.89-1.35)$ & 0.311 \\
\hline \multicolumn{8}{|l|}{ Device thrombosis } \\
\hline Definite & 26 & $(2.9)$ & 5 & $(0.5)$ & 5.27 & $(2.02-13.72)$ & $<0.001$ \\
\hline Probable & 4 & $(0.4)$ & 3 & $(0.3)$ & 1.34 & $(0.30-5.99)$ & 0.701 \\
\hline Possible & 5 & $(0.6)$ & 10 & $(1.1)$ & 0.51 & $(0.17-1.48)$ & 0.203 \\
\hline Definite/probable device thrombosis & 30 & $(3.3)$ & 8 & $(0.9)$ & 3.80 & $(1.74-8.28)$ & $<0.001$ \\
\hline$\leq 24 \mathrm{~h}$ (acute) & 3 & & 3 & & & & \\
\hline$>24 \mathrm{~h}$ to $30 \mathrm{~d}$ (subacute) & 10 & & 2 & & & & \\
\hline $31 \mathrm{~d}$ to 1 y (late) & 8 & & 1 & & & & \\
\hline $1-2$ y (very late) & 9 & & 2 & & & & \\
\hline Any device thrombosis & 35 & (3.9) & 18 & $(2.0)$ & 1.98 & $(1.12-3.49)$ & 0.017 \\
\hline
\end{tabular}

